Article

\title{
High-Performance Recovery of Cobalt and Nickel from the Cathode Materials of NMC Type Li-Ion Battery by Complexation-Assisted Solvent Extraction
}

\author{
Wen-Yu Wang * (D), Hong-Chi Yang and Ren-Bin Xu \\ Department of Environmental Engineering and Management, Chaoyang University of Technology, \\ Taichung 41349, Taiwan; sslt1161@gmail.com (H.-C.Y.); xu10225617@yahoo.com.tw (R.-B.X.) \\ * Correspondence: wywang@cyut.edu.tw; Tel.: +886-4-2332-3000
}

Received: 22 June 2020; Accepted: 24 July 2020; Published: 26 July 2020

check for updates

\begin{abstract}
The annual global volume of waste lithium-ion batteries (LIBs) has been increasing over years. Although solvent extraction method seems well developed, the separation factor between cobalt and nickel is still relatively low-only 72 when applying conventional continuous-countercurrent extraction. In this study, we improved the separation factor of cobalt and nickel by complexation-assisted solvent extraction. Before solvent extraction procedure, leaching kinetic of $\mathrm{Li}, \mathrm{Ni}, \mathrm{Co}$ and $\mathrm{Mn}$ was studied and can be explained by the Avrami equation. Leached residues were also investigated by SEM and XRD. Operation parameters of complexation-assisted solvent extraction were examined, including volume ratio of extractant to diluent, types of diluent, type of complexing reagent, extractant saponification percentage and volume ratio of organic phase to aqueous phase. The optimal separation factor of complexation-assisted solvent extraction could be improved to 372, which is five times that of conventional solvent extraction. The separation tendency would be interpreted by the relationship between extraction equilibrium $\mathrm{pH}$ and log distribution coefficient.
\end{abstract}

Keywords: recycling lithium-ion batteries; solvent extraction; complexing reaction; cobalt; nickel

\section{Introduction}

Secondary lithium-ion batteries (LIBs) featuring high-energy densities and reasonable costs are widely used for energy storage in electronic devices and electric vehicles. A variety of LIBs designed for different purposes are made from different cathode materials. To date, the seven most commonly used cathode materials are lithium iron phosphate (LFP), lithium cobalt oxide $\left(\mathrm{LiCoO}_{2}\right)$, lithium manganese oxide (LMO), lithium nickel oxide (LNO), lithium nickel cobalt aluminum oxide (NCA), lithium titanate oxide (LTO), and lithium nickel manganese cobalt oxide (NMC) [1].

Global usage of NMC type LIBs has grown significantly in the past decade [2]. However, lifetime of LIBs is only about five years, which makes high-performance methods for recycling the valuable contents in the spent NMC type LIBs a critical requirement for the industry. It is worth mention that metals in these cathode materials are valuable. Cobalt is the highest value in most types of cathode materials $[3,4]$. Cobalt is widely distributed in igneous and sedimentary rocks and also present in meteorites (i.e., iron-nickel metal contains a few tenths of a percent cobalt), but cobalt reserves are very scarce. It is average content in the Earth's crust is approximately $25-30 \mathrm{ppm}$, though widely distributed, ranks only 33rd in the order of abundance, and is less common than all other transition metals except scandium [5]. Currently, the price for cobalt ( $\$ 35,700$ per ton) is comparable to lithium $\left(\sim \$ 38,100\right.$ per ton, equivalent to $\$ 6350$ per ton of $\left.\mathrm{LiOH} \cdot \mathrm{H}_{2} \mathrm{O}\right)$, which is much more expensive than those of manganese ( $\sim 1500$ per ton) and nickel ( $\$ 14,600$ per ton), respectively (metal.com, June 2020).

Recently, the interest for recycling cobalt from spent LIBs has grown rapidly. Several review articles have summarized the processes and technologies for recycling these metals, especially the ones 
using hydrometallurgy techniques [6-14]. Normally, a metal leaching procedure is needed to recover spent LIBs. Many researchers have used organic acid leaching and have reported that the operation conditions and metal leaching percentages which are shown in Table 1 [15-23], but most of these studies focus only on cathode materials of $\mathrm{LiCoO}_{2}$. Nevertheless, the metal extraction percentage in some organic acid solution systems is not high enough for the recovery and separation of different metals from ternary metal oxide, i.e., NMC. As shown in Table 2, there are also some studies using inorganic acid leaching solution [24-33]. Among them, acid leaching solution added with reducing agent has higher efficiency for cathodic metals. Therefore, in this study we used $\mathrm{H}_{2} \mathrm{SO}_{4}$ as leaching solution and $\mathrm{H}_{2} \mathrm{O}_{2}$ as reducing agent. Other studies applied biohydrometallurgy or bioleaching techniques were also reported $[34,35]$. Calvert et al. studied the recycling of metals from leachate of waste LIBs using hydrogen sulfide generated by a consortium of sulfate-reducing bacteria in a lactate-fed fluidized bed reactor [36]. Calvert's study displayed a high recovery percentage with $96 \%$ metals in the leachate, however, the process is unable to separate individual metal.

The high similarity of chemical properties of cobalt and nickel makes the separation of cobalt and nickel with comparable concentration challenging. The chemical precipitation method and electrolytic recovery technology are only suitable for recycling high cobalt content with trace nickel impurity. For the leachate with mixed metals (Co, Ni, Mn, $\mathrm{Li}, \mathrm{Al}$ and $\mathrm{Cu}$ ) from cathodic metals of spent NMC type LIBs, as the ratio of nickel (or manganese) to cobalt increases greatly, co-precipitation or co-electrodeposition of cobalt, nickel and manganese will result in a significant reduction in purity. Our previous study work on recovering cobalt in a leachate (leaching with $\mathrm{H}_{2} \mathrm{SO}_{4}$ and $\mathrm{H}_{2} \mathrm{O}_{2}$ ) from $\mathrm{LiNi}_{1 / 3} \mathrm{Mn}_{1 / 3} \mathrm{Co}_{1 / 3} \mathrm{O}_{2}$ (NMC 111) LIBs by electrolytic plating. However, even at the optimal operating conditions, the purity was only $62.2 \%$ [37].

Table 3 lists the separation technologies for separating and recovering the metal species in the leachate from cathode materials of spent LIBs. These technologies include aqueous two-phase systems [38], solvent extraction [39,40], microemulsion extraction [41], ionic liquid [42], polymer inclusion membrane containing extractant [43] and hollow fiber supported liquid membrane [44]. Some studies worked on the synergetic effect of complexing agent in leaching process for spent LIBs $[45,46]$, but only a few studies investigated on the synergetic effect of complexing agent in solvent extraction process [47].

Among these technologies, solvent extraction process is the most studied one. The term solvent extraction refers to the distribution of a solute between two immiscible liquid phases in contact with each other, i.e., a two-phase distribution of a solute [48]. The solute is the metals dissolved in the leaching aqueous solution from waste (e.g., spent LIBs). The two immiscible liquid phases are the organic phase of extractant blended with diluent and the leaching aqueous solution. Pagnanelli et al. targeted on recycling Co from end of life LIBs [49] using cathodic powder of LIBs which containing metal oxides going through a series of treatments to obtain a cobalt carbonate product. The process in their study included (1) a selective extraction stage by P-204 for removing Mn; (2) another selective extraction stage by Cyanex 272 for extraction of Co; (3) a stripping stage by sulfuric acid to transfer Co ions to aqueous phase; and (4) a precipitation stage by sodium carbonate to produce the final product of cobalt carbonate. With optimized conditions, the purity of cobalt carbonate could be as high as $95 \%$.

This study investigated and optimized a continuous-countercurrent-extraction process for the separation of Mn, Co, Ni and Li from the spent NMC 111 LIBs and a facile recovery technology of complexation-assisted solvent extraction for highly efficient separation of Co and Ni. 
Table 1. Recent research for cathodic metals leaching by organic acid.

\begin{tabular}{|c|c|c|c|c|c|c|}
\hline $\begin{array}{c}\text { Organic Acid/Reducing } \\
\text { Agent Used }\end{array}$ & Cathode Materials & Temperature $\left({ }^{\circ} \mathrm{C}\right)$ & Leaching Time (min) & $\begin{array}{l}\text { Co Leaching } \\
\text { Percentage }(\%)\end{array}$ & $\begin{array}{c}\text { Li Leaching } \\
\text { Percentage }(\%)\end{array}$ & Reference \\
\hline $\begin{array}{c}\text { 2-M DL-malic acid } \\
6 \text { vol } \% \mathrm{H}_{2} \mathrm{O}_{2}\end{array}$ & $\begin{array}{c}\mathrm{LiCoO}_{2} \\
\mathrm{LiMn}_{2} \mathrm{O}_{4} \\
\end{array}$ & 95 & 60 & 90 & 90 & [15] \\
\hline $\begin{array}{l}\text { 2-M L-tartaric acid } \\
4 \mathrm{vol} \% \mathrm{H}_{2} \mathrm{O}_{2}\end{array}$ & $\begin{array}{c}\mathrm{LiCoO}_{2} \\
\mathrm{LiNi}_{0.5} \mathrm{Co}_{0.2} \mathrm{Mn}_{0.3} \mathrm{O}_{2}\end{array}$ & 70 & 30 & 98.6 & 99.1 & [16] \\
\hline $\begin{array}{l}\text { 1-M iminodiacetic acid } \\
0.02-\mathrm{M} \text { ascorbic acid }\end{array}$ & $\mathrm{LiCoO}_{2}$ & 80 & 120 & 99.0 & 90.0 & [17] \\
\hline $\begin{array}{c}\text { 1-M maleic acid } \\
0.02-\mathrm{M} \text { ascorbic acid }\end{array}$ & $\mathrm{LiCoO}_{2}$ & 80 & 120 & 99.0 & 96.0 & [17] \\
\hline $\begin{array}{c}\text { 0.5-M glycine } \\
0.02-\mathrm{M} \text { ascorbic acid }\end{array}$ & $\mathrm{LiCoO}_{2}$ & 80 & 120 & 91.0 & - & [18] \\
\hline $\begin{array}{l}\text { 0.4-M tartaric acid } \\
0.02-\mathrm{M} \text { ascorbic acid }\end{array}$ & $\mathrm{LiCoO}_{2}$ & 80 & 60 & 93.0 & 95.0 & [19] \\
\hline $\begin{array}{c}\text { 2-M citric acid } \\
0.6 \mathrm{~g} / \mathrm{g} \mathrm{H}_{2} \mathrm{O}_{2}\left(\mathrm{H}_{2} \mathrm{O}_{2} / \mathrm{LIBs}\right)\end{array}$ & $\mathrm{LiCoO}_{2}$ & 70 & 80 & 96.0 & 98.0 & [20] \\
\hline 1-M oxalic acid & $\mathrm{LiCoO}_{2}$ & 95 & 150 & 97.0 & 98.0 & [21] \\
\hline $\begin{array}{c}\text { 1.5-M succinic acid } \\
4 \mathrm{vol} \% \mathrm{H}_{2} \mathrm{O}_{2}\end{array}$ & $\mathrm{LiCoO}_{2}$ & 70 & 40 & 100.0 & 96.0 & [22] \\
\hline $\begin{array}{l}\text { 1-M oxalic acid } \\
5 \mathrm{vol} \% \mathrm{H}_{2} \mathrm{O}_{2}\end{array}$ & $\mathrm{LiCoO}_{2}$ & 80 & 120 & 96.7 & - & [23] \\
\hline
\end{tabular}


Table 2. Recent research for cathodic metals leaching by inorganic acid.

\begin{tabular}{|c|c|c|c|c|c|c|}
\hline $\begin{array}{c}\text { Inorganic Acid/Reducing } \\
\text { Agent Used }\end{array}$ & Cathode Materials & Temperature $\left({ }^{\circ} \mathrm{C}\right)$ & Leaching Time (min) & $\begin{array}{l}\text { Co Leaching } \\
\text { Percentage }(\%)\end{array}$ & $\begin{array}{c}\text { Li Leaching } \\
\text { Percentage (\%) }\end{array}$ & Reference \\
\hline 4-M HCl & $\mathrm{NCA}\left(\mathrm{LiNi}_{0.8} \mathrm{Co}_{0.15} \mathrm{Al}_{0.05} \mathrm{O}_{2}\right)$ & 90 & 1080 & 100 & 100 & [24] \\
\hline $4-\mathrm{M} \mathrm{HCl}$ & NCA scrap & 80 & 60 & $>99$ & $>96$ & [25] \\
\hline $\begin{array}{c}3-\mathrm{M} \mathrm{HCl} \\
3.5 \mathrm{vol} \% \mathrm{H}_{2} \mathrm{O}_{2}\end{array}$ & Mobile phones batteries $\mathrm{LiCoO}_{2}$ & 80 & 60 & 89 & 89 & [26] \\
\hline $\begin{array}{c}2-\mathrm{M} \mathrm{H}_{2} \mathrm{SO}_{4} \\
5 \mathrm{vol} \% \mathrm{H}_{2} \mathrm{O}_{2}\end{array}$ & Mobile phones batteries $\mathrm{LiCoO}_{2}$ & 75 & 60 & 70 & 99.1 & [27] \\
\hline $\begin{array}{c}2-\mathrm{M} \mathrm{H}_{2} \mathrm{SO}_{4} \\
3 \mathrm{vol} \% \mathrm{H}_{2} \mathrm{O}_{2}\end{array}$ & $\begin{array}{l}\text { Cathode materials } \\
\mathrm{LiNi}_{0.5} \mathrm{Co}_{0.2} \mathrm{Mn}_{0.3} \mathrm{O}_{2}\end{array}$ & 60 & 60 & $>99$ & $>99$ & [28] \\
\hline $\begin{array}{c}\text { 2.5- }-\mathrm{M} \mathrm{H}_{2} \mathrm{SO}_{4} \\
3.3 \mathrm{vol} \% \mathrm{H}_{2} \mathrm{O}_{2}\end{array}$ & $\begin{array}{l}\text { Mixture of } \mathrm{LiCoO}_{2}, \mathrm{LiMn}_{2} \mathrm{O}_{4} \\
\qquad \mathrm{LiNiO}_{2}, \mathrm{LiNi}_{\mathrm{x}} \mathrm{Co}_{\mathrm{y}} \mathrm{Mn}_{\mathrm{z}} \mathrm{O}_{2}\end{array}$ & 90 & 120 & $>99$ & $>99$ & [29] \\
\hline $\begin{array}{c}4-\mathrm{M} \mathrm{H}_{2} \mathrm{SO}_{4} \\
10 \mathrm{vol} \% \mathrm{H}_{2} \mathrm{O}_{2} \\
\end{array}$ & $\begin{array}{l}\text { Mobile phones batteries } \\
\text { mainly } \mathrm{LiCoO}_{2}\end{array}$ & 85 & 120 & 95 & 96 & [30] \\
\hline $\begin{array}{c}6-\mathrm{M} \mathrm{H}_{2} \mathrm{SO}_{4} \\
5 \mathrm{vol} \% \mathrm{C}_{2} \mathrm{H}_{5} \mathrm{OH}\end{array}$ & $\begin{array}{l}\text { spent cell phones batteries } \\
\qquad \mathrm{LiCoO}_{2}\end{array}$ & 90 & 160 & $>99$ & $>99$ & [31] \\
\hline $\begin{array}{c}1-\mathrm{M} \mathrm{H}_{2} \mathrm{SO}_{4} \\
0.075-\mathrm{M} \mathrm{NaHSO}_{3}\end{array}$ & $\begin{array}{c}\text { PCs/laptops batteries } \mathrm{LiCoO}_{2} \\
\mathrm{Li}_{2} \mathrm{CoMn} \mathrm{O}_{8},\left(\mathrm{Li}_{0.85} \mathrm{Ni}_{0.05}\right)\left(\mathrm{NiO}_{2}\right)\end{array}$ & 95 & 240 & 91.6 & 96.7 & [32] \\
\hline $\begin{array}{c}1.5-\mathrm{M} \mathrm{H}_{2} \mathrm{SO}_{4} \\
5 \mathrm{vol} \% \mathrm{H}_{2} \mathrm{O}_{2} / 5 \mathrm{~g} \mathrm{C}_{5} \mathrm{H}_{8} \mathrm{O}_{4}\end{array}$ & $\begin{array}{l}\text { Laptops batteries } \\
\text { mainly } \mathrm{LiCoO}_{2}\end{array}$ & 90 & 120 & 88 & 100 & [33] \\
\hline
\end{tabular}


Table 3. Recent research for recovering and separation of cathodic metals from spent lithium-ion batteries (LIBs).

\begin{tabular}{|c|c|c|c|}
\hline Technologies & Characteristic & Conclusion & Reference \\
\hline Aqueous two-phase systems & $\begin{array}{c}\text { Separation of cobalt and nickel in } \\
\text { leach solutions }\end{array}$ & $\begin{array}{l}\text { The best separation conditions were achieved using } 2-\mathrm{N} \text { as extracting agent, } \mathrm{pH} 5.00 \text {, } \\
\text { sodium sulfate, L } 64 \text { copolymer, TP:BP ratio } 1: 1 \text { and a } 35-\text { dilution factor of the liquor. } \\
\text { Under these conditions, } 99.19 \% \text { cobalt and } 10.81 \% \text { nickel extraction were obtained. }\end{array}$ & {$[38]$} \\
\hline Solvent extraction & $\begin{array}{l}\text { Recovery metals from LIBs NMC } \\
\text { cathode materials }\end{array}$ & $\begin{array}{l}\text { The optimal parameters obtained in leaching were } 2.0 \mathrm{~mol} / \mathrm{L} \text { of } \mathrm{H}_{2} \mathrm{SO}_{4}, 30 \mathrm{~mL} / \mathrm{g} \text {, } \\
70{ }^{\circ} \mathrm{C} \text { and } 90 \mathrm{~min} \text {. The results showed that } 0.1-\mathrm{M} \text { Na-Cyanex } 272 \text { should first be } \\
\text { used as the extractant to separate cobalt and nickel under the optimal condition of } \\
\text { pH 6. Then, cobalt and manganese should be separated by using } 0.2-\mathrm{M} \mathrm{Na-D2EHPA} \\
\text { at equilibrium pH 2.95. Nickel and lithium can be separated by using DMG at pH 9. }\end{array}$ & {$[39,40]$} \\
\hline Microemulsion extraction & $\begin{array}{l}\text { Selective recovery of cobalt from } \\
\text { NMC type LIBs }\end{array}$ & $\begin{array}{l}\text { With the assistance of probe type ultrasonication, manganese could be } \\
\text { simultaneously separated by precipitation. Next, water-in-oil microemulsion } \\
\text { extraction was applied for direct extraction of cobalt from the other metals. } \\
\text { The cobalt extraction yield was } 98 \% \text { and purity was } 96 \% \text {. }\end{array}$ & {$[41]$} \\
\hline Ionic liquid & $\begin{array}{l}\text { Cobalt(II)/nickel(II) separation } \\
\text { from sulfate media }\end{array}$ & $\begin{array}{l}\text { The separation of cobalt(II) and nickel(II) with }[\mathrm{C} 101][\mathrm{Cl}] \text { and }[\mathrm{C} 101][\mathrm{SCN}] \text { was } \\
\text { investigated by extraction from sulfate media. Co(II) extraction was close to } 100 \% \\
\text { while no extracted } \mathrm{Ni}(\mathrm{II}) \text { could be detected. Extraction did not follow the } \\
\text { split-anion mechanism but occurred through a regular anion-exchange mechanism. }\end{array}$ & {$[42]$} \\
\hline $\begin{array}{l}\text { Polymer inclusion membrane } \\
\text { containing extractant }\end{array}$ & $\begin{array}{l}\text { Separation of cobalt(II) from } \\
\text { manganese(II) }\end{array}$ & $\begin{array}{c}\mathrm{Co}(\mathrm{II}) \text { separation and preconcentration has been demonstrated by the complete } \\
\text { transfer of } \mathrm{Co}(\mathrm{II}) \text { from a feed solution containing a similar concentration of } \mathrm{Mn}(\mathrm{II}) \\
\text { into a sulfuric acid receiving solution with less than } 5 \% \mathrm{Mn}(\mathrm{II}) \text { being transported } \\
\text { during the same period. }\end{array}$ & {$[43]$} \\
\hline $\begin{array}{l}\text { Hollow-fiber supported liquid } \\
\text { membrane }\end{array}$ & $\begin{array}{l}\text { Separation of Co(II) and } \mathrm{Li}(\mathrm{I}) \\
\text { with Cyanex } 272\end{array}$ & $\begin{array}{l}\mathrm{Co}(\mathrm{II}) \text { and } \mathrm{Li}(\mathrm{I}) \text { was prepared by dissolving calculated amount of } \mathrm{CoSO}_{4} \text { and } \\
\mathrm{Li}_{2} \mathrm{SO}_{4} \text {. A complete separation of both the metals with } 99.99 \% \text { purity can be } \\
\text { achieved by HFSLM process using Cyanex } 272 \text { as a mobile carrier. }\end{array}$ & {$[44]$} \\
\hline
\end{tabular}




\section{Materials and Methods}

\subsection{Reagents and Materials}

Sulfuric acid $\left(\mathrm{H}_{2} \mathrm{SO}_{4} ; 98 \%\right)$; hydrogen peroxide $\left(\mathrm{H}_{2} \mathrm{O}_{2} ; 35 \%\right)$; sodium hydroxide $(\mathrm{NaOH} ; \geq 98 \%)$; cobalt powder (Co; 99\%); nickel powder (Ni; 99\%); ICP multielement standard solution IV (99\%), cyclohexane $\left(\mathrm{C}_{6} \mathrm{H}_{12} ; 99 \%\right)$, sodium acetate $\left(\mathrm{C}_{2} \mathrm{H}_{3} \mathrm{NaO}_{2} ; 99 \%\right)$ and ammonium acetate $\left(\mathrm{C}_{2} \mathrm{H}_{7} \mathrm{NO}_{2}\right.$; $98 \%$ ) were all purchased from Merck (Darmstadt, Germany). Toluene $\left(\mathrm{C}_{7} \mathrm{H}_{8} ; 99 \%\right)$; heptane $\left(\mathrm{C}_{7} \mathrm{H}_{16} ;\right.$ $99 \%)$; octane $\left(\mathrm{C}_{8} \mathrm{H}_{18} ; 99 \%\right)$; nonane $\left(\mathrm{C}_{9} \mathrm{H}_{20} ; 99 \%\right)$; decane $\left(\mathrm{C}_{10} \mathrm{H}_{22} ; 99 \%\right)$; citric acid $\left(\mathrm{C}_{6} \mathrm{H}_{8} \mathrm{O}_{7} ; 99.5 \%\right)$; ammonium thiocyanate $\left(\mathrm{NH}_{4} \mathrm{SCN} ; 99 \%\right)$; sodium thiocyanate $\left(\mathrm{Na}_{4} \mathrm{SCN} ; 99 \%\right)$ and succinic acid $\left(\mathrm{C}_{4} \mathrm{H}_{6} \mathrm{O}_{4} ; 99 \%\right)$ were all purchased from Acros (Fair Lawn, NJ, USA). Sodium citrate $\left(\mathrm{C}_{6} \mathrm{H}_{5} \mathrm{Na}_{3} \mathrm{O}_{7} \cdot 2 \mathrm{H}_{2} \mathrm{O}_{\text {; }}\right.$ 99\%) and kerosene $\left(\mathrm{C}_{n} \mathrm{H}_{2 n+2}, 10 \leq \mathrm{n} \leq 16\right)$ were purchased from PanReac AppliChem (Barcelona, Spain) and CPC Corporation (Chiayi, Taiwan), respectively. Di(2-ethylhexyl)phosphoric acid (P-204; $\geq 95 \%$ ) and 2-ethyl(hexyl)phosphonic acid mono-2-ethylhexyl ester (P-507; $\geq 95 \%$ ) were selected as manganese extractants and cobalt extractants, respectively. All of the above reagents were used as they were received. The spent lithium-ion batteries (Model no. 5099130N) containing ternary cathode materials of lithium nickel manganese cobalt oxide $\left(\mathrm{LiNi}_{1 / 3} \mathrm{Mn}_{1 / 3} \mathrm{Co}_{1 / 3} \mathrm{O}_{2} ; \mathrm{NMC} 111\right)$ were supplied by Amita Technologies, Inc., Taoyuan, Taiwan.

\subsection{Instrumentation}

The analysis of metal concentration was carried out using inductively coupled plasma atomic emission spectroscopy (ICP-AES) from Thermo ICAP-6000 (Waltham, MA, USA). The hydrogen ion concentration was measured using digital pH-meter of HI-5222 from Hanna (Woonsocket, RI, USA). Flask shaker is from Shin Kwang (New Taipei City, Taiwan) FS-6 U. The surface morphology of cathode powder and leached residue was determined by a field-emission scanning electron microscopy (SEM, JSM-7401F, JEOL, Tokyo, Japan). The crystalline phase of cathode powder and leached residue were measured by X-ray diffraction (XRD, XRD-6000, Shimadzu, Kyoto, Japan, with Cu-K $\alpha$ radiation, $\lambda=1.54056 \AA$ ). XRD spectra were collected in the $2 \theta$ range from $5^{\circ}$ to $90^{\circ}$ with scan rate of $2^{\circ} \mathrm{min}^{-1}$.

\subsection{Summary of Flow Sheet}

The flow sheet, for recovering cobalt from the cathode materials of spent LIBs was illustrated as Figure 1. The recovering procedure of spent LIBs includes the portions of discharging, dismantling, pretreatment, leaching, solvent extraction of manganese and conventional solvent extraction or complexation-assisted solvent extraction of cobalt. The spent batteries were discharged before dismantling. Then, the cathode materials (NMC powder) coated on top of the aluminum foils were collected for pretreatment. In the pretreatment step, sodium hydroxide solution was selected as leaching reagent for dissolution of aluminum foil and detritus. Then, the NMC powder could be filtered out of the solution, collected, dried and leached by $4-\mathrm{N}$ sulfuric acid and hydrogen peroxide. Because the cobalt leaching percentage is greater than $99 \%$ in this condition, the solid to liquid ratio in the leaching process is 1:15. After subtracting oxygen (as $\mathrm{LiNi}_{0.33} \mathrm{Mn}_{0.33} \mathrm{Co}_{0.33} \mathrm{O}_{2}$ ) and insoluble residue of graphite, the total metal concentration in leachate is about $35 \mathrm{~g} / \mathrm{L}$. The metal concentrations are about $10 \mathrm{~g} / \mathrm{L}$ for $\mathrm{Mn}, \mathrm{Co}$ and Ni, respectively. Afterwards, manganese was removed by a three-stage solvent extraction process. The organic extract phase with high purity cobalt could be obtained by applying a six-stage conventional solvent extraction process or a single one-stage complexation-assisted solvent extraction assisted by complexation with ammonium thiocyanate. Finally, the stripped solution including only high purity of cobalt could then undergo electrowinning to obtain metallic cobalt or precipitating to obtain cobalt salt. 


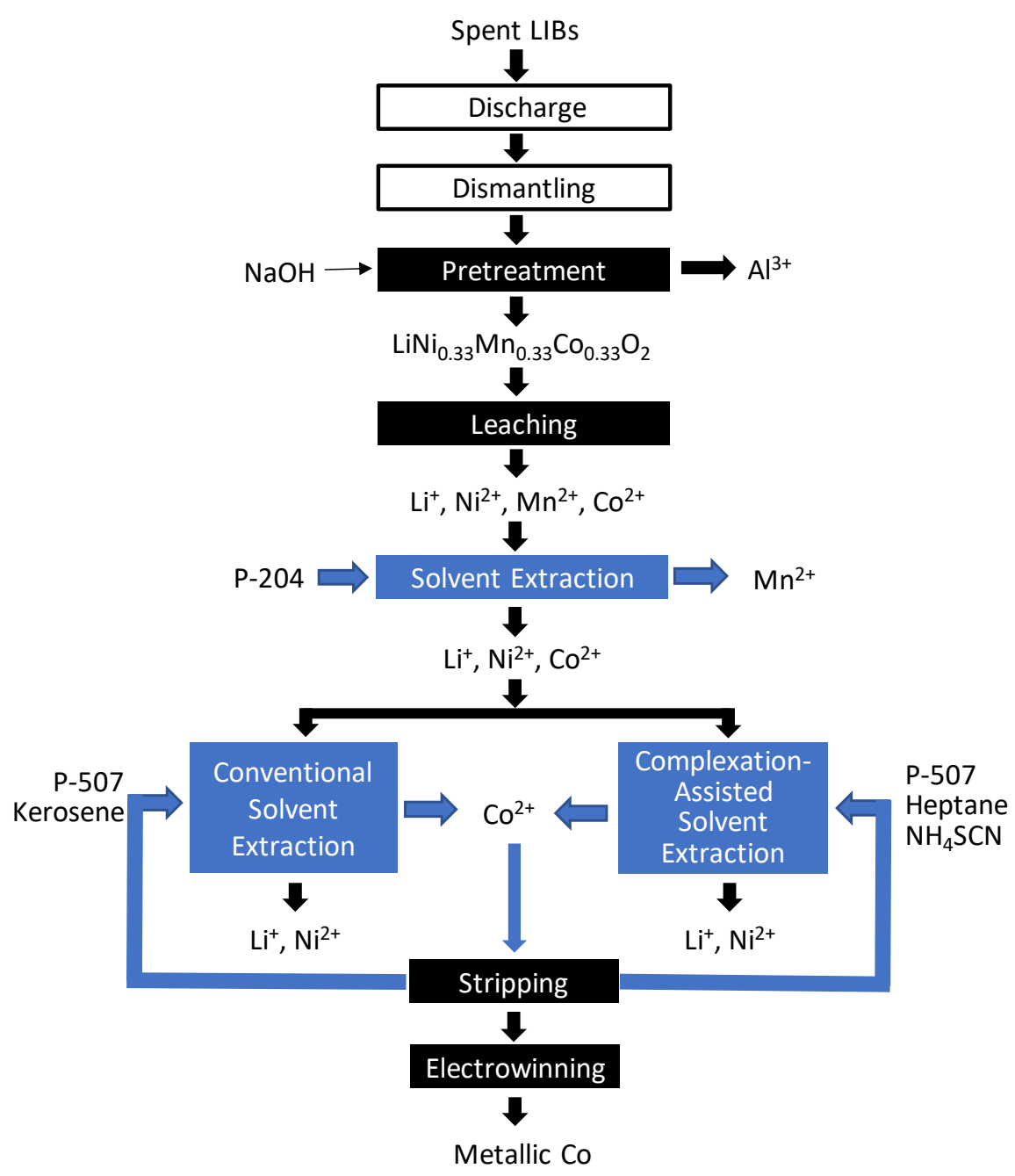

Figure 1. Flow sheet for recovering cobalt from the cathode materials of spent LIBs. Blue blocks represent organic phase and black blocks represent aqueous phase.

\subsection{Continuous-Countercurrent-Extraction Process and Mixing-Clarification Extraction Tank}

A bench scale self-made mixing-clarification extraction tank shown as Figure 2, was used for the solvent extraction process. The extraction tank has multicompartments for mixing, clarification, organic phase (blend of extractant and diluent) collection and aqueous phase (leach liquor) collection. The effective total volume of the extraction tank is $3 \mathrm{~L}$. Volume for each compartment in the extraction tank is $1 \mathrm{~L}$ for mixing, $1.5 \mathrm{~L}$ for clarification, $0.25 \mathrm{~L}$ for organic phase collection and $0.25 \mathrm{~L}$ for aqueous phase collection, respectively. The mixing compartment is equipped with a motor with a propeller. The propeller can suck aqueous leach liquor and organic extractant from the different inlets. During the continuous-countercurrent-extraction process shown as Figure 3, several extraction tanks in series were used, where manganese or cobalt was mixed with the organic phase by countercurrent contact and extracted from the aqueous phase.

When; $\mathrm{Co}_{\mathrm{n}, \mathrm{M}}(\mathrm{n}=1-6$ in Figure 3) was outlet metal $(\mathrm{M}=\mathrm{Mn}, \mathrm{Co}, \mathrm{Ni}$ or $\mathrm{Li})$ concentration of organic phase at the $n$th stage extraction tank; $\mathrm{CO}_{n+1, M}$ is inlet metal concentration of organic phase at the nth stage tank; $\mathrm{Ca}_{\mathrm{n}-1, \mathrm{M}}$ is inlet metal concentration of aqueous phase at the nth stage tank; and $\mathrm{Ca}_{n, M}$ is outlet metal concentration of aqueous phase at the nth stage tank. $\mathrm{Co}_{\mathrm{i}, \mathrm{M}}$ is the feeding metal concentration of organic phase at the last stage tank and its metals concentrations are normally equal to zero. $\mathrm{Ca}_{\mathrm{i}, \mathrm{M}}$ is feeding metal concentration of aqueous phase at the first stage tank and its metal concentrations are normally equal to that of fresh acid leaching solution. 


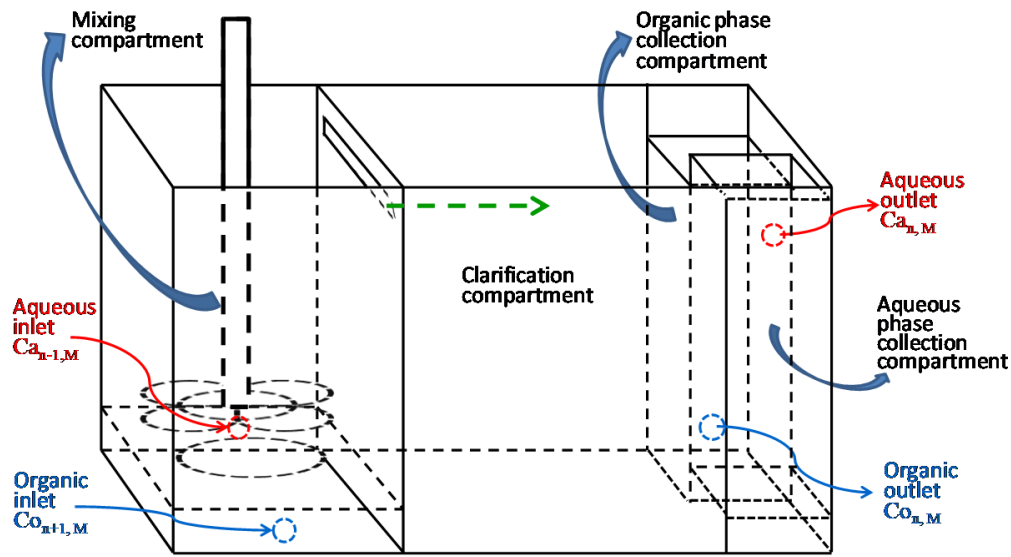

Figure 2. Structure of the bench scale self-made mixing-clarification extraction tank.

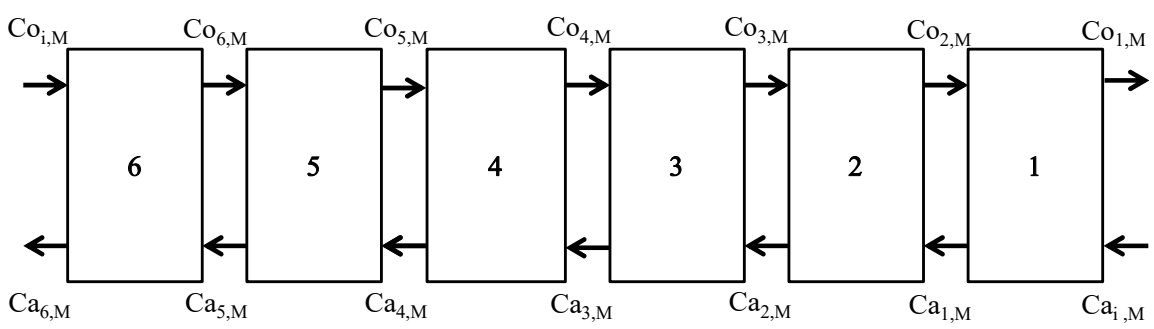

Figure 3. Continuous-countercurrent-extraction process.

Then, the mixed liquor overflowed into the clarification compartment and subsequently separated into an upper organic phase and a lower aqueous phase, respectively. Afterwards, the upper organic phase overflowed into the organic phase collection compartment and was sucked to the organic extractant inlets of the previous extraction tank. Lower aqueous phase flowed to the aqueous phase collection compartment and circuit to aqueous inlets of the next extraction tank.

When the leachate and extractant are brought together in the solvent extraction process, the metal (solute M) will distribute itself between the aqueous phase and the organic phase. At equilibrium, the ratio of this distribution is called the distribution coefficient (D).

$$
\mathrm{D}_{\mathrm{M}}=\mathrm{Co}_{\mathrm{M}} / \mathrm{Ca}, \mathrm{M}
$$

A typical parameter of the separation factor is defined to express selectivity of the extractant for one metal (solute A) over another metal (solute B).

$$
\beta_{\mathrm{A} / \mathrm{B}}=\mathrm{D}_{\mathrm{A}} / \mathrm{D}_{\mathrm{B}}
$$

The separation factor must be greater than unity in order to separate A from B by solvent extraction, just as the relative volatility must be greater than unity to separate A from B by distillation [50].

\subsection{Sequential Solvent Extraction of Manganese and Cobalt}

In a typical trial, the organic phase was made-up by extractant and diluent. Extractant P-204 and P-507 were, respectively, blended in a diluent for making a $20 \%$ by volume concentration. Next, P-204 and P-507 were saponified by sodium hydroxide, respectively. The $\mathrm{pH}$ of the aqueous phase was adjusted for extraction of manganese and cobalt, respectively by adding sodium hydroxide. After that, the organic phase and the aqueous phase (leaching solution after de-aluminum) were put together inside a separation funnel $(\mathrm{O} / \mathrm{A}$ ratio $=1: 1)$. The funnel was shaken for $30 \mathrm{~min}$. After phase separation was complete, the organic phase was stripped with 1-N sulfuric acid to elute manganese or 
cobalt out. The collected aqueous phase was repeatedly extracted several times and collected for further experiments and analyses. In the continuous-countercurrent-extraction process, the organic phase and the aqueous phase were continuously pumped into the inlet tank, respectively. The extraction equilibrium state can be examined by visual observation of the solution color and chemical analysis.

\subsection{Complexation-Assisted Solvent Extraction of Cobalt}

After the extraction of manganese, next step will be extraction of cobalt, which can be carried out by a conventional solvent extraction process as described in the previous paragraph or the facile complexation-assisted solvent extraction process. After that, P-507 was blended with various diluents for making a $20 \%$ by volume concentration. These diluents include cyclohexane, heptane, toluene, heptane, octane, nonane and decane. In addition, several possible complexing reagents were chosen as candidates for extraction of cobalt including citric acid, sodium citrate, succinic acid, sodium thiocyanate and ammonium thiocyanate. Other operation parameters were the same as described in the previous paragraph. In order to control the initial metals concentrations in different experiments, cobalt powder and nickel powder were used as substitutes of cathode materials from spent LIBs. In addition, the cathode materials from spent LIBs were also examined with the optimum operation parameters of complexation-assisted solvent extraction process.

\section{Results and Discussion}

\subsection{Disassembly and Composition Analysis of Spent LIBs}

The spent ternary secondary lithium battery cells were discharged and disassembled. The weight percentage analysis results of the disassembled materials were $2.54 \%$ of outer packaging, $5.89 \%$ of separator, $15.00 \%$ of copper foil, $26.63 \%$ of anode materials, $6.74 \%$ of aluminum foil and $43.20 \%$ of cathode materials including stuck aluminum detritus. The metal compositions of cathode materials (with stuck aluminum detritus) were examined. The ratios of $\mathrm{Ni}, \mathrm{Mn}, \mathrm{Co}$ and $\mathrm{Li}$ were 0.37:0.39:0.38:1, which was comparable to the cathode composition of NMC 111.

\subsection{Removal of Aluminum and Leaching of Cathode Powder Materials}

After disassembly, cathode materials and stuck aluminum detritus were dissolved and filtered by alkali and then the aluminum content was analyzed. There was $7.18 \%$ of aluminum remaining in the $43.20 \%$ of cathode powder materials and stuck aluminum detritus. Next, the filtered residues were leached with $\mathrm{H}_{2} \mathrm{SO}_{4}$ and $\mathrm{H}_{2} \mathrm{O}_{2}$. After another filtration, a leached residue of graphite and a metals solution were obtained. The metals contents of leached solution were $10.30 \mathrm{~g} / \mathrm{L}$ of $\mathrm{Mn}, 10.75 \mathrm{~g} / \mathrm{L}$ of Co, $10.45 \mathrm{~g} / \mathrm{L}$ of $\mathrm{Ni}$ and $3.12 \mathrm{~g} / \mathrm{L}$ of $\mathrm{Li}$.

Figure 4 shows SEM images of recovered cathode powder and leached residue. Compared with the recovered cathode powder (Figure 4a,b), the surface morphologies of leached residue (Figure 4c,d) have plenty of pores with different sizes. $\mathrm{Li}$ and coworkers studied the valences of $\mathrm{Ni}$, $\mathrm{Co}$ and $\mathrm{Mn}$ in the NMC 111 LIBs by XPS. They found out that NMC consists of $\mathrm{Ni}^{2+}, \mathrm{Mn}^{4+}$ and $\mathrm{Co}^{3+}$ in the as-made materials. After battery charging cycle, XPS peaks is considered to be $\mathrm{Co}^{3+}, \mathrm{Mn}^{4+}$ and composite signal of $\mathrm{Ni}^{2+}$ and $\mathrm{Ni}^{3+}$ [51]. However, many literatures report ionic charges of manganese, nickel and cobalt in leaching solution from cathode materials are all +2 .

Figure 5 presents XRD patterns of recovered cathode powder and leached residue. The XRD pattern of recovered cathode powder shows several reflection peaks which match with previously reported pure single phase of $\mathrm{LiNi}_{1 / 3} \mathrm{Co}_{1 / 3} \mathrm{Mn}_{1 / 3} \mathrm{O}_{2}$ [52]. Comparing with the pattern of reported pure single phase, there are many noises in the patterns of recovered cathode powder because of impurity from spent LIBs. The pattern of leached residue shows a dominated reflection at $26.4^{\circ}$ of $2 \theta$ which is the same as the reported diffraction patterns of the pure graphite powders [53]. Besides, leached residue also shows a few lower intensity peaks from remaining cathode powder. On the other hand, 
the reflection pattern of cathode powder shows no reflection at $26.4^{\circ}$ of $2 \theta$. The reason could be that graphite is shielded by cathode powder.

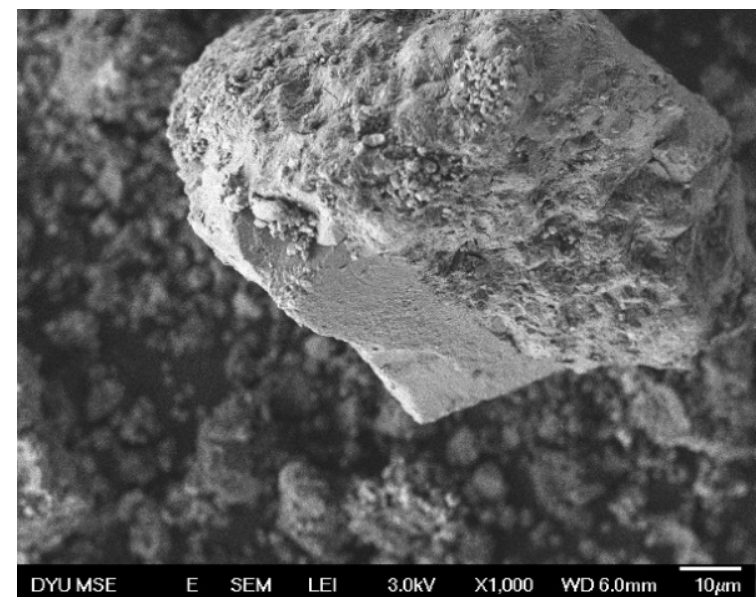

(a)

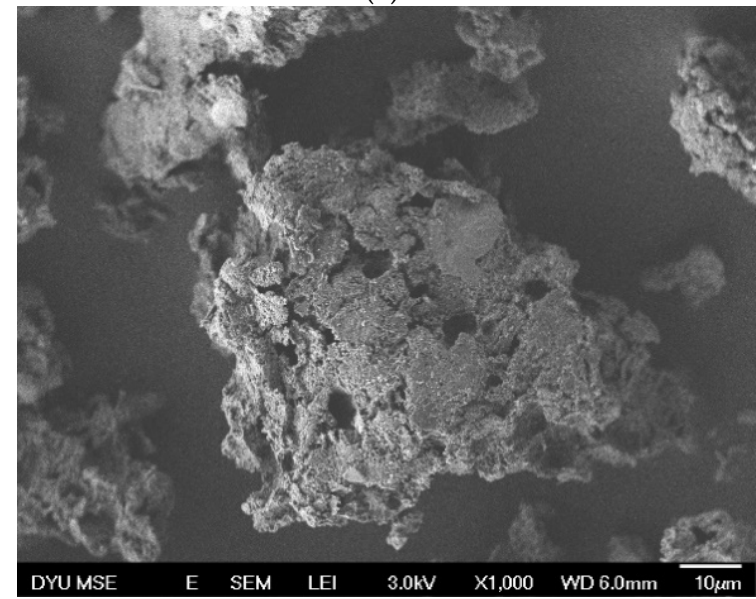

(c)

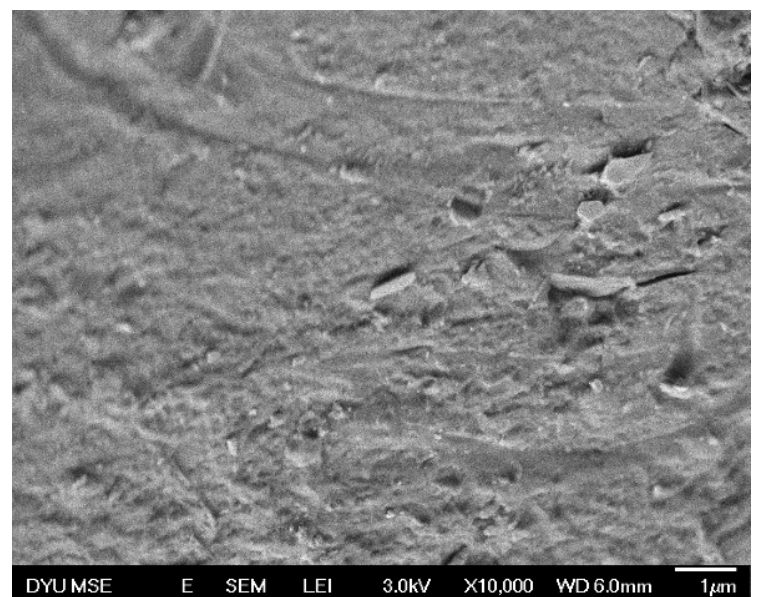

(b)

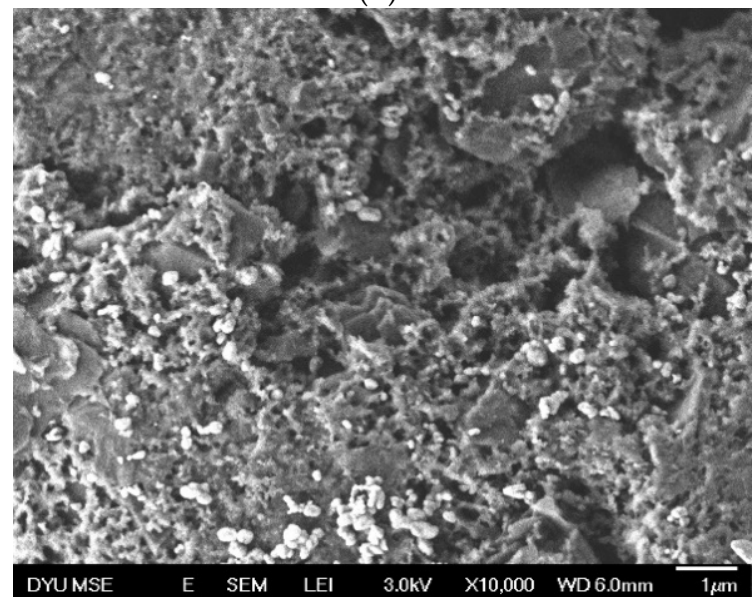

(d)

Figure 4. SEM images of (a) recovered cathode powder $(1000 \times)$, (b) recovered cathode powder $(10,000 \times),(\mathbf{c})$ leached residue $(1000 \times)$ and $(d)$ leached residue $(10,000 \times)$. (Leaching conditions: 4-N sulfuric acid; $35 \%$ wt. $\mathrm{H}_{2} \mathrm{O}_{2}: 3 \%$ v/v; solid/liquid: $1: 15 \mathrm{w} / \mathrm{v} ; 50{ }^{\circ} \mathrm{C} ; 3 \mathrm{~h}$ ).

Various kinetics of leaching processes were studied by several studies. Among these leaching kinetics, Avrami equation is well verified for crystallization and later extended to other heterogeneous reaction systems [54]. Avrami equation is presented as $\ln (-\ln (1-x))=\ln k+n \ln (t)$, where $x$ is the leaching efficiency of a metal; $\mathrm{k}$ is the reaction rate constant $\left(\mathrm{min}^{-1}\right)$; $t$ indicates leaching time $(\mathrm{min})$ and $\mathrm{n}$ is a fitting parameter. Its integration form is $\mathrm{x}=1-\exp \left(-\mathrm{kt}^{\mathrm{n}}\right)$. In the Avrami equation, particular assumptions regarding leaching reaction and diffusion result in exact values of these constants. Zhang et al. researched cobalt leaching process in trichloroacetic acid with $\mathrm{H}_{2} \mathrm{O}_{2}$ media [55]. They indicated that the Avrami equation could be well used to describe the leaching process of cathode scraps. We also applied Avrami equation to study kinetic of leaching process. Figure 6 shows correlation of $\ln (-\ln (1-x))$ to $\ln (t)$ of lithium, nickel, manganese and cobalt, respectively in different leaching media. 


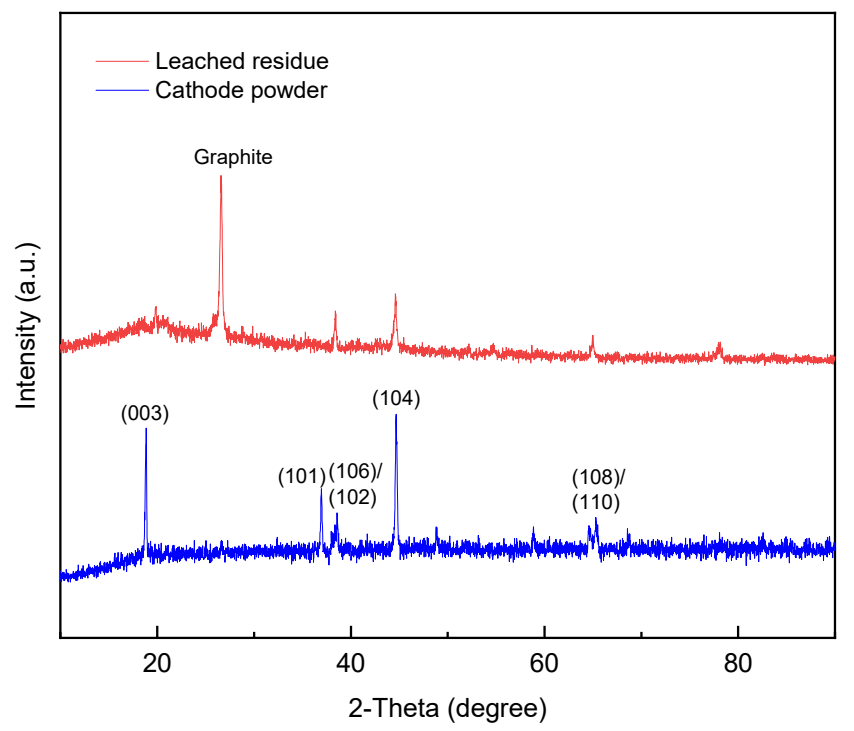

Figure 5. XRD patterns of recovered cathode powder and leached residue.

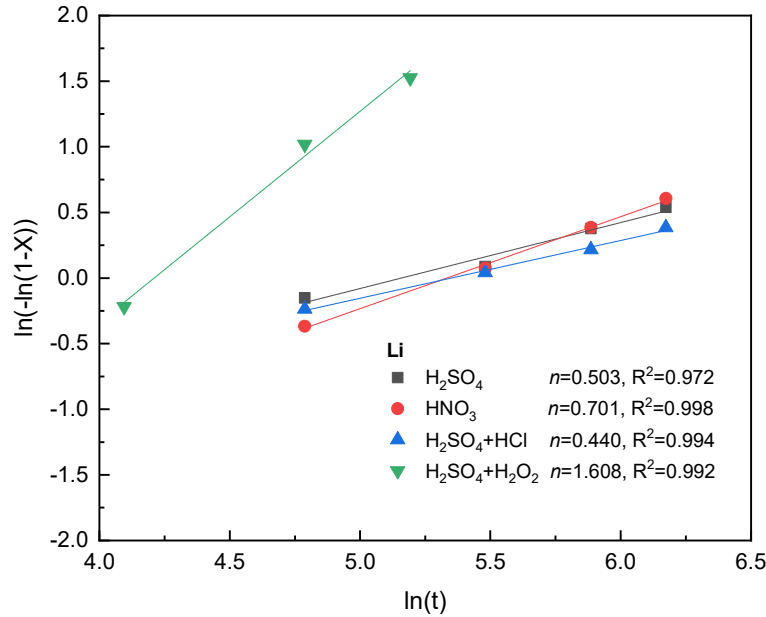

(a)

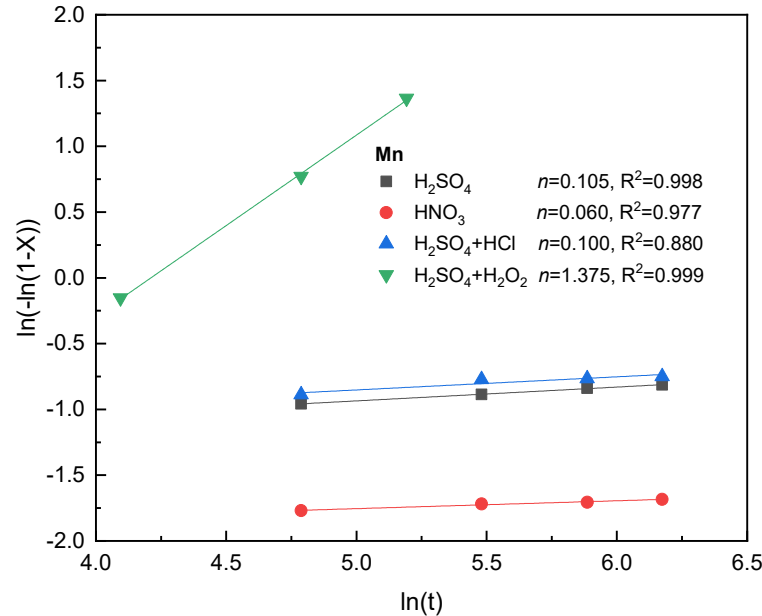

(c)

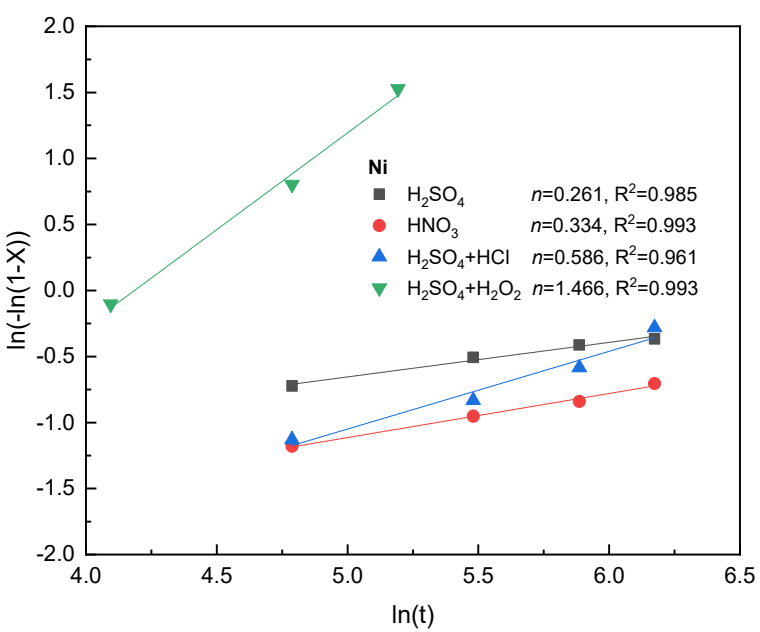

(b)

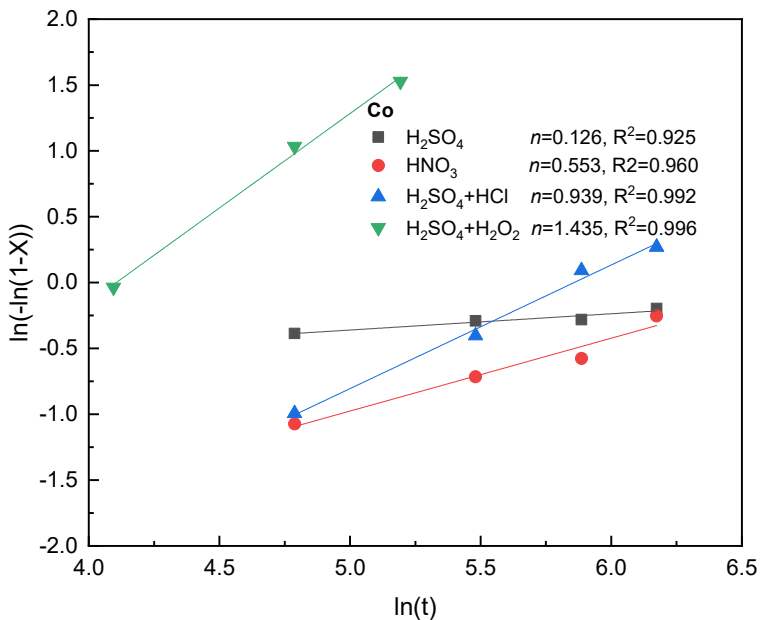

(d)

Figure 6. Plots of $\ln (-\ln (1-X))$ to $\ln (t)$ of (a) lithium, (b) nickel, (c) manganese, and (d) cobalt in different acids (leaching conditions: acid molarity: $4 \mathrm{~N}$; solid/liquid: $1: 15 \mathrm{w} / \mathrm{v} ; 65^{\circ} \mathrm{C}$ and $480 \mathrm{~min}$; except for $\mathrm{H}_{2} \mathrm{SO}_{4}+\mathrm{H}_{2} \mathrm{O}_{2}$ at $50{ }^{\circ} \mathrm{C}$ and $180 \mathrm{~min}$ ). 
Most of the $\mathrm{R}^{2}$ values in Figure 6 are higher than 0.95 , which indicates the validity of linearly fitting by Avrami equation. The value of $\mathrm{n}$ in $\mathrm{H}_{2} \mathrm{SO}_{4}+\mathrm{H}_{2} \mathrm{O}_{2}$ leaching for each meatal is the highest, which shows that reducing agent $\left(\mathrm{H}_{2} \mathrm{O}_{2}\right)$ greatly increases the leaching efficiency. The values of $\mathrm{n}$ in mixing acid leaching system $\left(\mathrm{H}_{2} \mathrm{SO}_{4}+\mathrm{HCl}\right)$ for lithium, nickel and cobalt are from 0.44 to 0.94 , which shows that the leaching rate is high at first and then goes down over time before leaching equilibrium is reached. In addition, it can be discovered from Figure 6a that the values of $n$ in different leaching systems for lithium are obviously higher than that of other three metals, which indicates that the acid leaching lithium is easier than other metals. It can also be discovered from Figure $6 \mathrm{c}$ ) that the values of $\mathrm{n}$ for manganese are only about 0.1 for three different leaching systems except for $\mathrm{H}_{2} \mathrm{SO}_{4}$ $+\mathrm{H}_{2} \mathrm{O}_{2}$, which indicates that the acid leaching manganese without reducing agent is more difficult than other metals. In the following conventional solvent extraction process and complexation-assisted solvent extraction, we used the optimum leaching conditions of 4- $\mathrm{N} \mathrm{H}_{2} \mathrm{SO}_{4}, 3 \% v / v \mathrm{H}_{2} \mathrm{O}_{2}$ (35 wt. \%), $50{ }^{\circ} \mathrm{C}$ and $3 \mathrm{~h}$.

\subsection{Continuous-Countercurrent-Extraction Process}

After de-aluminum and leaching, the leachate of cathode materials was processed to remove manganese with $\mathrm{P}-204$ by a continuous-countercurrent-extraction process with three mixing-clarification tanks. When the extraction process reached equilibrium, two samples were taken from each tank including organic phase outlet and aqueous phase outlet. Figure 7 shows the metal concentrations of the feeding aqueous phase, feeding organic phase and inlet and outlet of each stage position in continuous-countercurrent-extraction process. The stage position numbers of 1,2 and 3 in Figure 7 are the same as the stage numbers in Figure 3. The terms Con, ${ }_{\mathrm{M}}$ and $\mathrm{Can}, \mathrm{M}$ are metal $\mathrm{M}(\mathrm{Mn}, \mathrm{Co}, \mathrm{Ni}$ or $\mathrm{Li})$ at nth stage in organic phase and aqueous phase, respectively. Feeding metal concentrations were showed as the first set of data at the rightmost side of Figure 7.

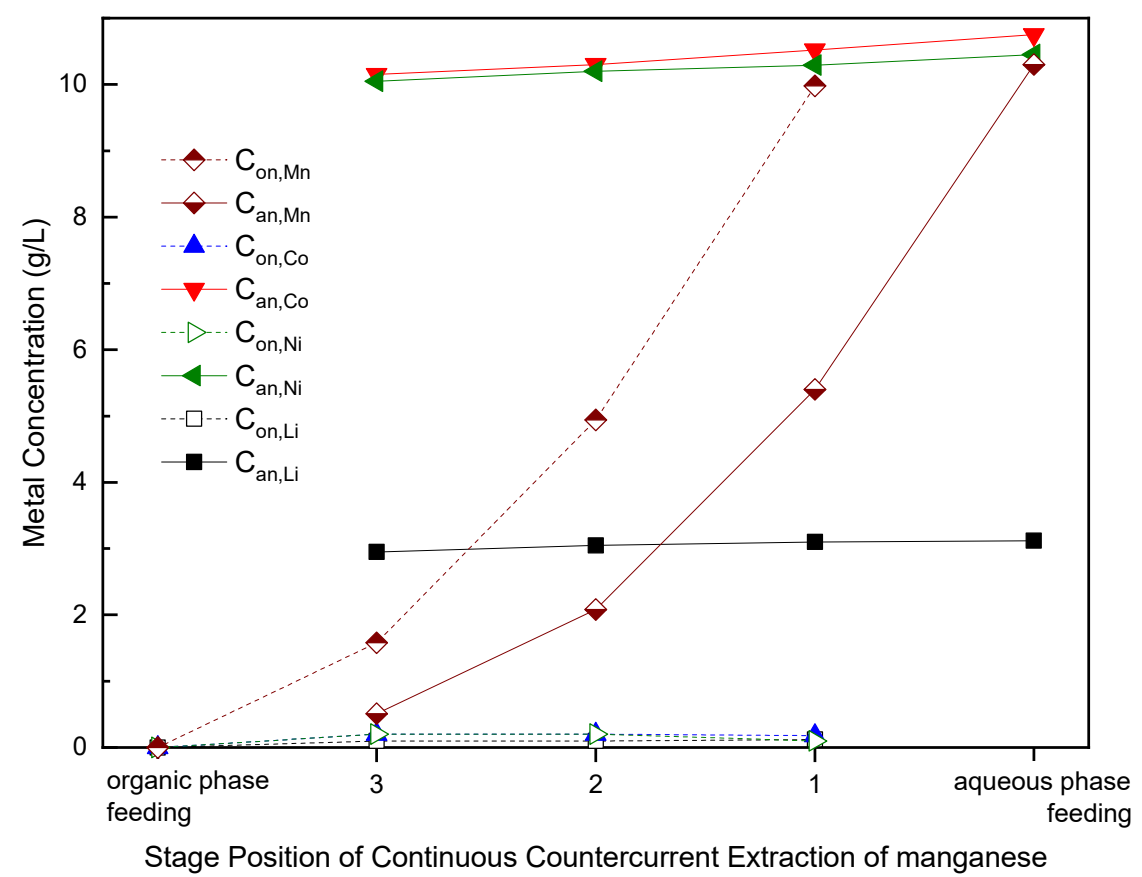

Figure 7. Metals concentrations in conventional continuous-countercurrent-extraction of manganese. P-204/kerosene-1:4 v/v; saponification: $60 \%$; O/A-1:1; retention time in each tank-5 min.

Figure 7 indicates that three stages are necessary for effective manganese removal from other metals in aqueous phase. Concentrations of $\mathrm{Co}, \mathrm{Ni}$ and $\mathrm{Li}$ in the aqueous phase slightly decrease from the inlet (feeding) at stage 1 to the final outlet at stage 3. Concentrations of $\mathrm{Mn}$ in the aqueous phase 
decrease from the inlet at stage 1 to the final outlet at stage 3. Simultaneously, concentrations of Mn in organic phase increase from the inlet (feeding) at stage 1 to the final outlet at stage 3 . The metals concentrations of $\mathrm{Mn}, \mathrm{Co}, \mathrm{Ni}$ and $\mathrm{Li}$ in the last extracted organic phase were 9.98, 0.20, 0.20 and $0.10 \mathrm{~g} / \mathrm{L}$. Furthermore, purity of Mn was $95 \%$ and can be improved subsequently by impurities scrubbing and manganese stripping. The separation factor of 108 157 $\left(\beta_{\mathrm{Mn} / \mathrm{Co}}\right), 121 \sim 190\left(\beta_{\mathrm{Mn} / \mathrm{Ni}}\right)$ and 48 91 $\left(\beta_{\mathrm{Mn} / \mathrm{Li}}\right)$ were obtained at different extraction stage. Joo et al. used P-507 and Versatic 10 acid to extract manganese and obtained separation factors of 9.4 24 ( $\left.\beta_{\mathrm{MnCo}}\right)$ and $46 \sim 329\left(\beta_{\mathrm{MnNi}}\right)$ [56]. Separation factors of $\beta_{\mathrm{Mn} / \mathrm{Co}_{0}}$ in this study is better than literature data.

After removal process of manganese, the raffinate (aqueous phase with trace manganese flow out from the last extraction stage) was fed to remove cobalt with P-507 by another continuous-countercurrent-extraction line with six mixing-clarification tanks. Figure 8 shows the metals concentrations of different streams in the extraction process.

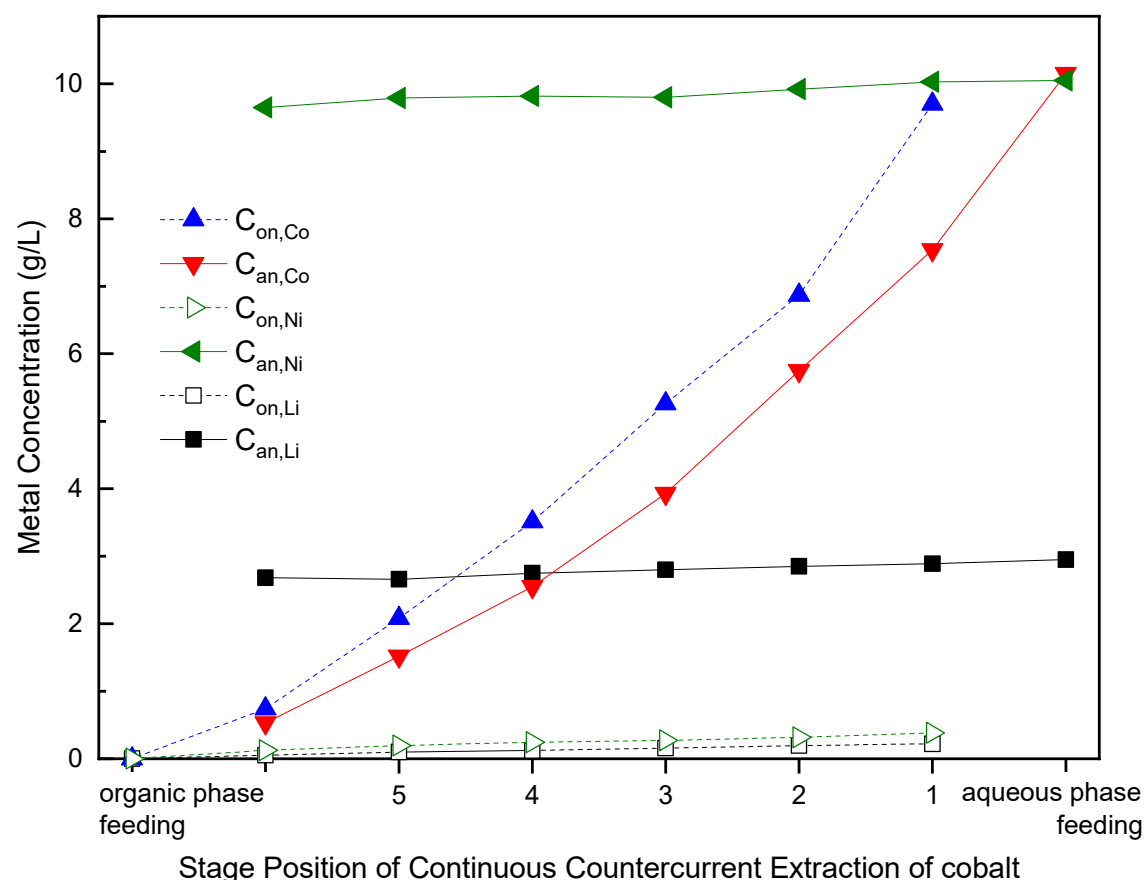

Figure 8. Metals concentrations in conventional continuous-countercurrent-extraction of cobalt. P-507/kerosene: 1:4 v/v; saponification: $60 \%$; O/A: 1:1; retention times in each tank: 5 min).

Figure 8 indicates that a six-stage process is necessary for effective cobalt removal from other metals in the aqueous phase. The stage position numbers of 1, 2, 3, 4, 5 and 6 in Figure 8 are the same as the stage numbers in Figure 3. The terms $\mathrm{Con}_{\mathrm{M}}$ and $\mathrm{Can}, \mathrm{M}$ are metal $\mathrm{M}(\mathrm{Co}, \mathrm{Ni}$ or $\mathrm{Li})$ at nth stage in organic phase and aqueous phase, respectively. Concentrations of $\mathrm{Ni}$ and $\mathrm{Li}$ in the aqueous phase slightly decrease from the inlet (feeding) at stage 1 to the final outlet at stage 6 . Concentrations of cobalt in aqueous phase decrease from the inlet at stage 1 to the final outlet at stage 6. Simultaneously, concentrations of $\mathrm{Co}$ in organic phase increase from the inlet (feeding) at stage 1 to the final outlet at stage 6. The metals concentrations of $\mathrm{Co}, \mathrm{Ni}$ and $\mathrm{Li}$ in the last extracted organic phase were 9.7, 0.38 and $0.22 \mathrm{~g} / \mathrm{L}$ at stage 1 . Furthermore, purity of Co was $94 \%$ and can be improved subsequently by impurities scrubbing and cobalt stripping. Our previous study demonstrated that the purity of plating cobalt foil can reach $98.80 \%$ [37] —or even up to $99.96 \%$ with deep impurity removal before cobalt electrowinning.

The distribution coefficients Equation (1) of cobalt were stable throughout the extraction process, but distribution coefficients of nickel decreased from stage 1 to stage 6 . Therefore, separation factors $\beta_{\mathrm{Co} / \mathrm{Ni}}$ increased from 34 (stage 1) to 109 (stage 6). The separation factors showed by this study 
were higher than that presented by Nguyen et al. which were 11 to 23 implemented by P-507 [57]. Nevertheless, metals extraction efficiency and separation factor depend on ratio between two competing metals, extractant concentration and equilibrium $\mathrm{pH}$ of the aqueous phase.

\subsection{Complexation-Assisted Solvent Extraction of Cobalt}

Both cobalt and nickel are transition metals arranged adjacent to each other on the periodic table, meaning that the physicochemical properties of the two elements are similar, leading to the difficulty in separating them. Subsequently, a six-stage extraction processes is required for separating cobalt and nickel by conventional solvent extraction. As a result of these problems, this study developed a complexation-assisted solvent extraction process with a specific diluent and a complexing reagent reducing number of extraction stages from six to one.

\subsubsection{Types of Diluent}

First, the effectiveness of diluents was investigated. The extraction and separation results are shown in Figure 9. The effectiveness of the diluents for the extraction of $\mathrm{Co}$ and $\mathrm{Ni}$ are presented as their extraction percentages. The separation factors $\beta_{\mathrm{Co} / \mathrm{Ni}}$ are 553, 227, 372, 263, 416, 416, 315 and 265 when using toluene, cyclohexane, heptane, octane, nonane, decane and kerosene, respectively.

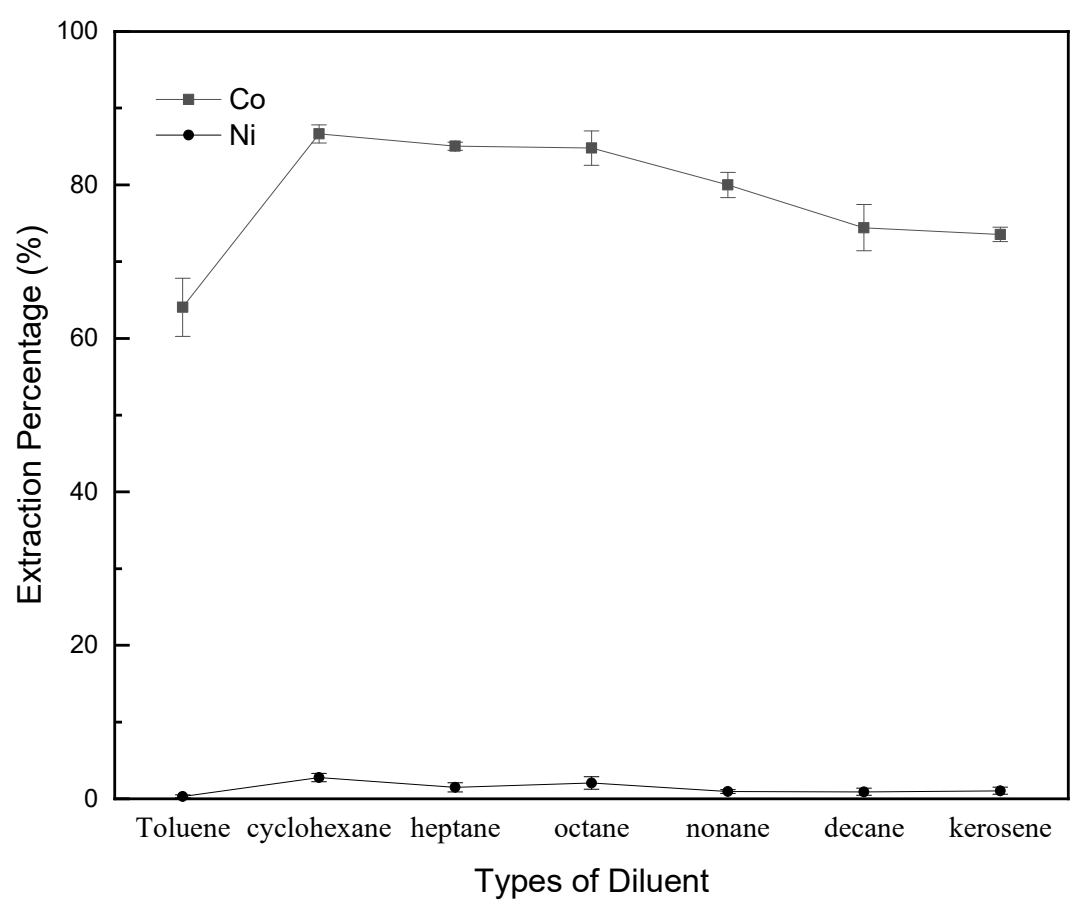

Figure 9. Effectiveness of different diluents for extraction percentages of cobalt and nickel. P-507/diluent-1:4 v/v; saponification: 60\%; complexing reagent-ammonium thiocyanate; $\mathrm{O} / \mathrm{A}-1: 1$ ).

By using toluene obtains the highest separation factor, but the lowest extraction percentage of Co and Ni. Toluene contains a $\pi$ bond with high polarity compared to the other diluents. This weakens the organic properties of the extractant in organic phase and reduces the distribution coefficient of cobalt complex in the oil/aqueous phases, thus results in the lowest cobalt extraction percentage. The result is similar with the literature reported by Ghebghoub and Barkat [58]. They studied the nature of diluents in the solvent extraction of $\mathrm{Cu}^{2+}$ from sulfate medium with P-204 as extractant. The literature reported that the extraction in cyclohexane was clearly improved to the presence only of the dimeric form of the molecules of extractant in the organic phase. For toluene, the extraction is weakest due to stronger interactions between extractant and the diluent, decreasing the activity of P-204. 
Additionally, cyclohexane, heptane, octane, nonane, decane and kerosene are all alkanes types of saturated hydrocarbons with low polarity. As the length of the carbon bond increases, the viscosity increases, leading to the difficulty for metal ions to ionized in the two phases. As a result, the shortest carbon bond of heptane has the highest extraction effectiveness.

Figure 9 also shows that it is difficult for P-507 blended with any kind of diluent to extract nickel ions. Wherein, the extraction percentage of cobalt with cyclohexane is the highest of $86.25 \%$, and that of nickel is only $2.77 \%$, but separation factor with heptane is higher than cyclohexane. However, kerosene is primarily used in industry, which is mainly based on the determination in consideration of the recovery percentage and the metal purity to economic costs. Therefore, it is to be known that the increase in the polarity of the diluent may decrease the extraction capability of the extracted organic phase. In addition, in the following sections, heptane was used as diluent for extracting cobalt.

\subsubsection{Saponification Percentage of Extractant}

In order to examine the effect of saponification, various amounts of sodium hydroxide were added to extractant P-507 before the extraction procedure. Figure 10 shows the extraction percentages tendency of cobalt and nickel corresponding to the saponification percentage of P-507 carried out in the complexation-assisted solvent extraction procedure.

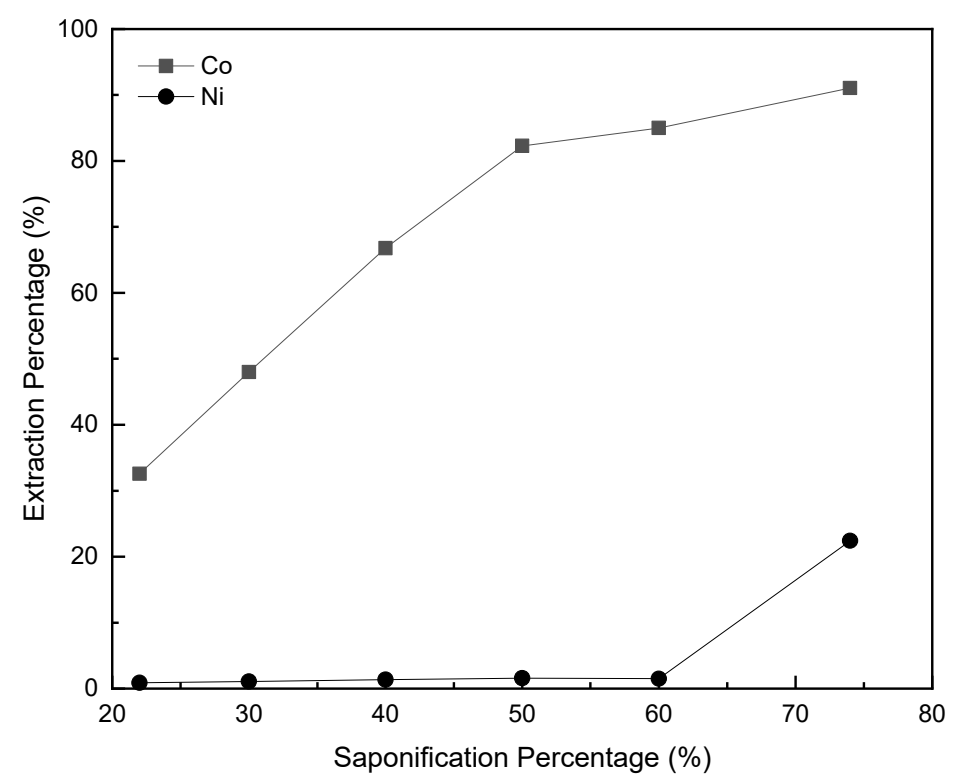

Figure 10. Extraction tendency of cobalt and nickel corresponding to saponification percentage. $\mathrm{P}-507 /$ heptane-1:4 v/v; complexing reagent-ammonium thiocyanate; $\mathrm{O} / \mathrm{A}-1: 1$ ).

When the saponification percentage rose from $20 \%$ to $60 \%$, the extraction percentage of cobalt increased from $33 \%$ to $86 \%$, but its nickel remained below $2 \%$. At $50 \%$ to $60 \%$ saponification ratio, the extraction equilibrium $\mathrm{pH}$ was between 4.5 and 5.2. When the saponification ratio reached $70 \%$, the cobalt extraction percentage become $91 \%$, the nickel extraction percentage increased to $22 \%$, and the extraction equilibrium $\mathrm{pH}$ was 6.2. The highest effectiveness was achieved when the saponification percentage was controlled at $60 \%$, regarding the extraction percentage and separation efficiency of cobalt and nickel.

\subsubsection{Types of Complexing Reagent}

In order to evaluate the effects of complexation on extraction of cobalt and nickel, various types of aqueous phase metal complexing reagents were investigated. Figure 11 indicates the extraction 
percentages of cobalt and nickel by different complexing reagents. Separation factors of cobalt and nickel were 2, 42, 18, 25, 525, 162, 372, 72 for citric acid, sodium citrate, succinic acid, sodium acetate, ammonium acetate, sodium thiocyanate, ammonium thiocyanate and blank (no complexing reagent added). We proposed ammonium thiocyanate as the best complexing reagent because of its better cobalt extraction capability, low nickel extraction percentage and a good separation factor. Although ammonium acetate has the highest separation factor with the highest cobalt extraction percentage, its nickel extraction percentage is too high and need additional step to remove nickel contents.

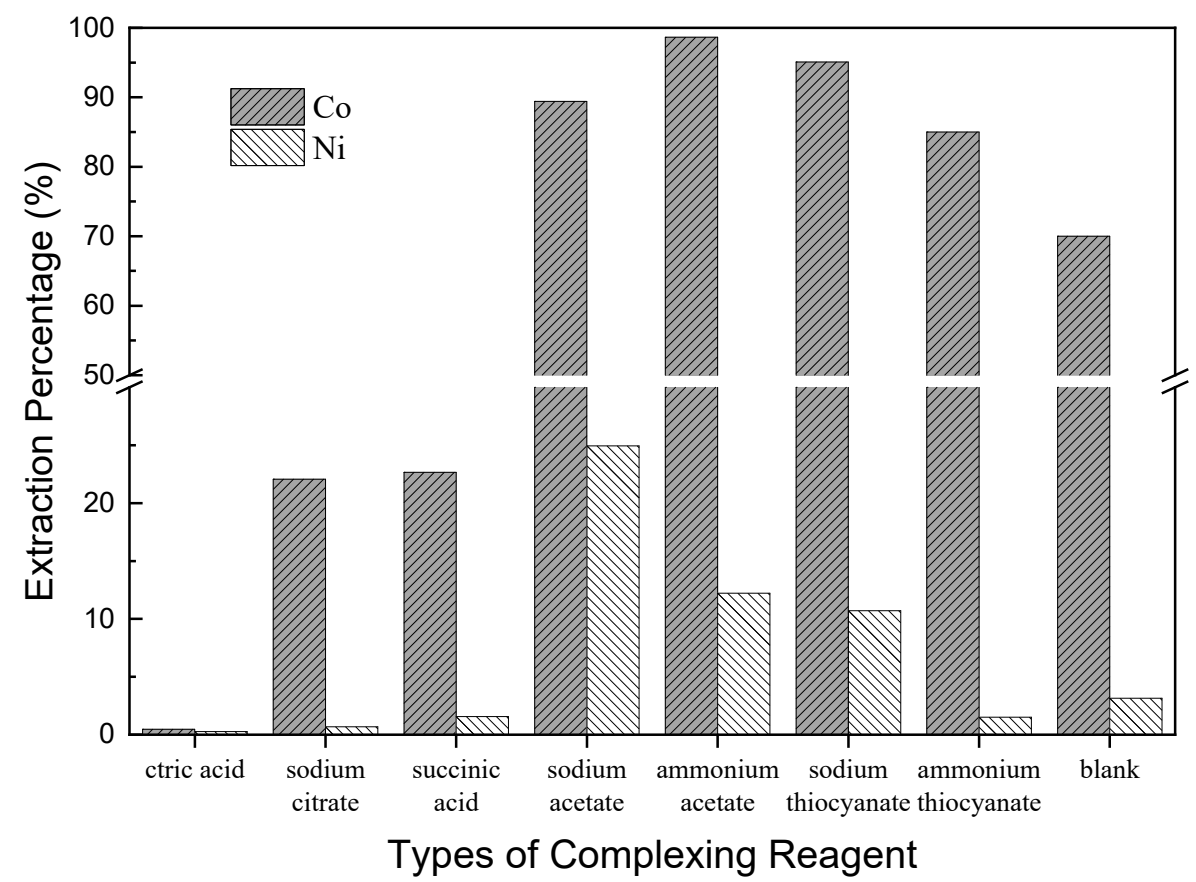

Figure 11. Extraction tendency of cobalt and nickel corresponding to types of complexing reagent. P-507/heptane-1:4 v/v; saponification: $60 \%$; O/A-1:1.

The complexing reagent acts as a ligand and complex with metal ions. For the negative electric metal complex, chloride ion or thiocyanate ion and so on, may be used as ligand. For the positive electric metal complex, an ammonium ion such as tetraethyl ammonium and so on, may be used as ligand. When the ligand ion is a negative electric specie (e.g., $\mathrm{SCN}^{-}$) and an acidic extractant (e.g., P-507) is used, we proposed a metal complex of $\mathrm{M}(\mathrm{SCN})_{2}\left(\mathrm{NH}_{4} \mathrm{SCN}\right)_{2}$ forms in aqueous phase in which $\mathrm{M}$ is $\mathrm{Co}$ or Ni. The metal extraction percentage is related not only to the structure and stability of the complexing reagent in the aqueous phase, but also to the stability of metal-extractant compound speciation in the organic phase. Kislik's report expressed complex forms of acidic organophosphorus extractant and transition metal [47]. At extraction of divalent transition metals (cobalt, nickel, copper) with acidic organophosphorus extractants, for example, P-204, nucleus metal-extractant aggregate is typically a tetraligated species- $\mathrm{Ni}(\mathrm{P}-204)_{2} \cdot 2 \mathrm{H}_{2} \mathrm{O} \cdot 2 \mathrm{P}-204$.

We suggest that transfer procedure could be a series of steps. First, the complex $\mathrm{M}(\mathrm{SCN})_{2}\left(\mathrm{NH}_{4} \mathrm{SCN}\right)_{2}(\mathrm{M}=\mathrm{Co}$ or Ni) forms in aqueous leachate, and then mixes with P-507 dimer or aggregate at organic-aqueous interface. Metal ions exchange to saponified P-507 and form a new complex $\mathrm{M}(\mathrm{P}-507)_{2} \cdot 2 \mathrm{H}_{2} \mathrm{O} \cdot 2(\mathrm{P}-507)$. Finally, metal ions transfer into the organic phase. The difference in stability between the cobalt complex and the nickel complex is very beneficial for separation in extraction process. The reason may be that $\mathrm{Co}(\mathrm{SCN})_{2}\left(\mathrm{NH}_{4} \mathrm{SCN}\right)_{2}$ is more conducive to directly perform an ion exchange of cobalt with saponified P-507.

However, when citrate ion or succinate ion acts as a complexing reagent the extraction percentages got a negative effect and were even worse than being blank. We proposed that acetate and succinate 
ions form more stable complexing products than the original cobalt and nickel hydrates. Thiocyanate ion and an organic amine alkaline extractant were once used in a cobalt-nickel hydrometallurgical system, but the extraction complex became too stable, which made stripping became difficult. Therefore, this study shown that when using acidic extractant P-507, ammonium thiocyanate is a better complexing reagent for the separation of cobalt and nickel.

\subsubsection{Organic/Aqueous Ratio}

As shown in Figure 12, when the organic/aqueous ratio was 1:4 and 1:2, the cobalt extraction percentage was only $29.95 \%$ and $57.37 \%$, respectively due to insufficient dose of extractants, the nickel extraction percentage was less than $1 \%$. When the organic/aqueous ratio was elevated to $1: 1$, the best separation effect was obtained. The extraction percentage of cobalt was $85.0 \%$, the extraction percentage of nickel was $1.5 \%$, the separation factor $\beta_{\mathrm{Co} / \mathrm{Ni}}$ could reach 372 .

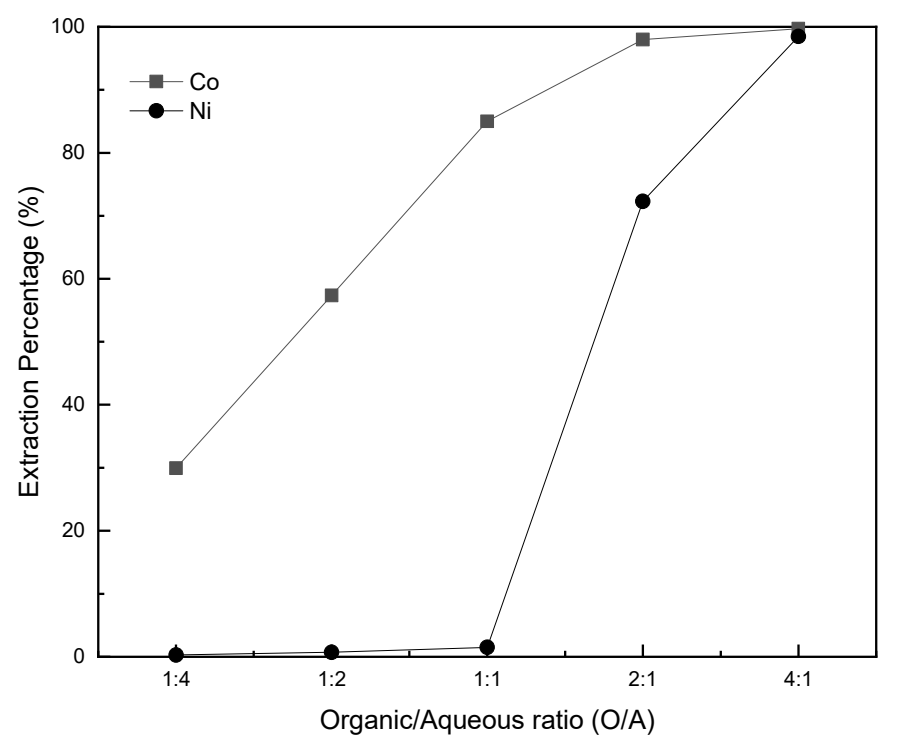

Figure 12. Extraction tendency of cobalt and nickel corresponding to organic/aqueous ratios. $\mathrm{P}-507 /$ heptane $-1: 4 \mathrm{v} / \mathrm{v}$; saponification-60\%; complexing reagent-ammonium thiocyanate.

If the organic/aqueous ratio increases continuously, it can be found that nickel enters the organic phase in large quantities, because of the excessive extractant and results in a poor separation between cobalt and nickel. When the organic/aqueous ratio reached 4:1, cobalt and nickel were almost completely extracted.

\subsubsection{Correlation of Extraction Equilibrium pH to Log Distribution Coefficient}

Figures 13 and 14 shows the correlation of extraction equilibrium $\mathrm{pH}$ to $\log$ distribution coefficient of cobalt and nickel, e.g., $\log \mathrm{D}_{\mathrm{Co}}$ and $\log \mathrm{D}_{\mathrm{Ni}}$, respectively. Figure 13 shows a linear relationship between $\log \mathrm{D}_{\mathrm{Co}}$ and extraction equilibrium $\mathrm{pH}$ from 3.9 to 6.1. The linear fitting slope is 1 , indicating that $\mathrm{D}_{\mathrm{Co}}(\mathrm{Co}, \mathrm{Co} / \mathrm{Ca}, \mathrm{Co})$ will become 10 times as hydroxide ion concentration increases 10 times. Therefore, we can adjust extraction equilibrium $\mathrm{pH}$ to control the cobalt distribution between the organic phase and the aqueous phase. As the equilibrium $\mathrm{pH}$ increases, the concentration of cobalt in the organic phase will increase as well, and more cobalt ions will transit from aqueous leachate to complex with organic extractant. 


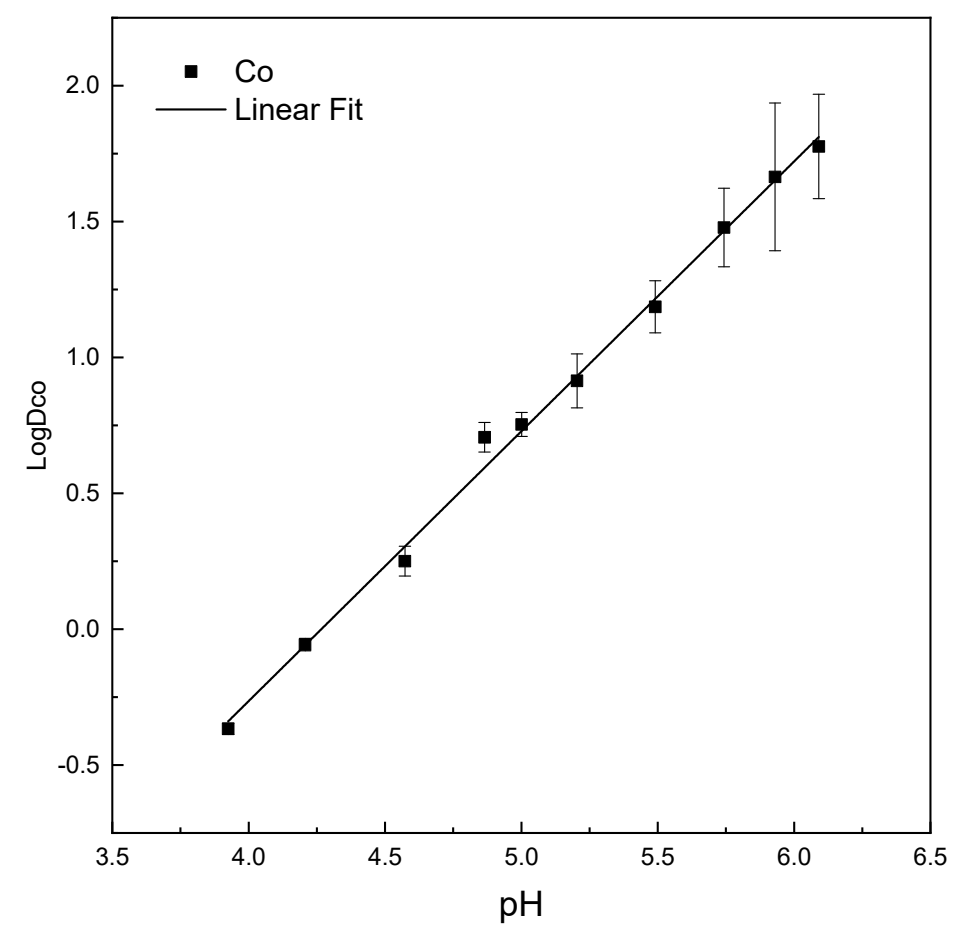

Figure 13. Correlation of extraction equilibrium $\mathrm{pH}$ to distribution coefficient of cobalt (Experimental conditions: $0.15-\mathrm{M}$ cobalt; 0.15-M nickel; 0.7-M ammonium thiocyanate; P-507/heptane-1:4 v/v; saponification: $60 \%$; $/ \mathrm{A}-1: 1$.

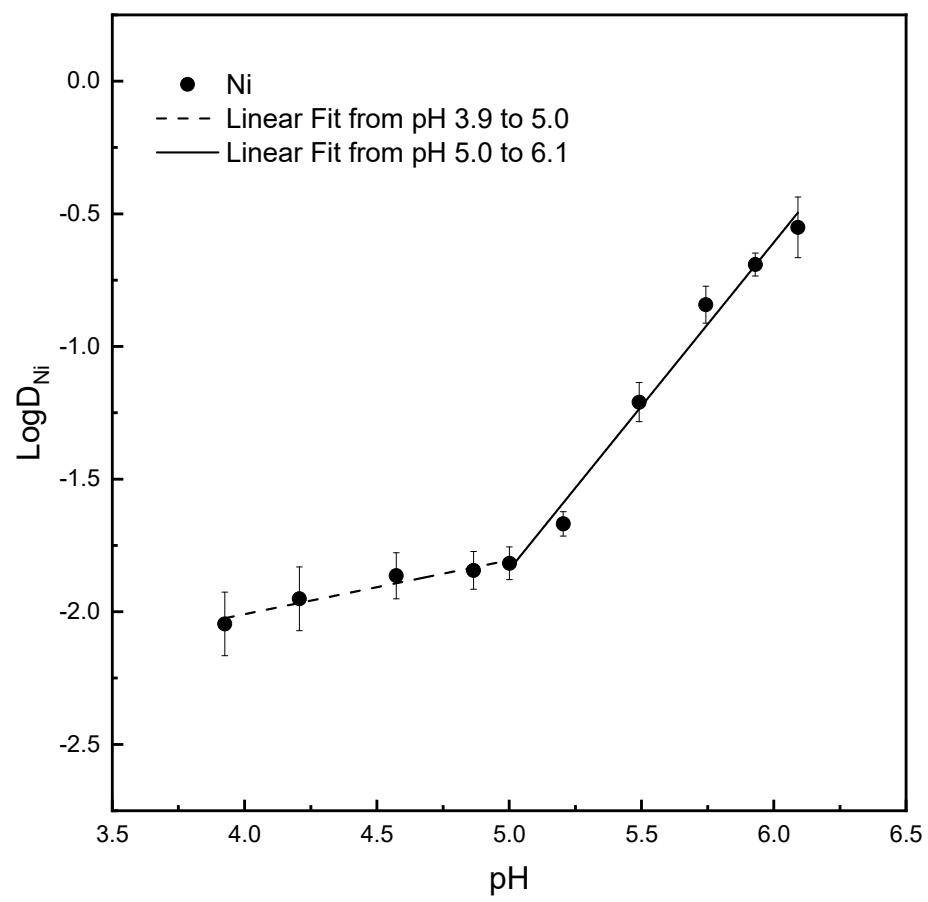

Figure 14. Correlation of extraction equilibrium $\mathrm{pH}$ to distribution coefficient of nickel. Experimental conditions were the same as described in Figure 13.

Figure 14 shows two segments of linear relationships between $\log \mathrm{D}_{\mathrm{Ni}}$ and extraction equilibrium $\mathrm{pH}$ from 3.9 to 5.0 and from 5.0 to 6.1, respectively. One linear fitting slope from $\mathrm{pH} 3.9$ to 5.0 is 0.2 . Another linear fitting slope from $\mathrm{pH} 5.0$ to 6.1 is 1.2 . The results indicated that $\mathrm{D}_{\mathrm{Ni}}(\mathrm{Co}, \mathrm{Ni} / \mathrm{Ca}, \mathrm{Ni})$ will 
increase only 1.6 times as hydroxide ion concentration increases 10 times during $\mathrm{pH}$ from 4 to 5 and increase 16 times as hydroxide ion concentration increases 10 times during $\mathrm{pH}$ from 5 to 6.

In other words, when the extraction equilibrium $\mathrm{pH}$ is in the range from 3.9 to 5.0, the slope of $\log \mathrm{D}_{\mathrm{Ni}}$ vs. $\mathrm{pH}$ is 0.2 , indicating that the distribution coefficient $\left(\mathrm{D}_{\mathrm{Ni}}\right)$ of nickel in the organic/aqueous phase only become 1.6 times as $\mathrm{pH}$ value increase 1 . In the meantime, the distribution coefficient $\left(\mathrm{D}_{\mathrm{Co}}\right)$ of cobalt in the organic/aqueous phase during the same $\mathrm{pH}$ range is 10 times. Along with increasing extraction equilibrium $\mathrm{pH}$ from 3.9 to 5.0, the concentration of cobalt in organic phase increases drastically while nickel increases slowly. The finding should be the same as we suggest in Section 3.4.3 that $\mathrm{Co}(\mathrm{SCN})_{2}\left(\mathrm{NH}_{4} \mathrm{SCN}\right)_{2}$ is more conducive to directly perform an ion exchange of cobalt with saponified P-507.

After the extraction equilibrium $\mathrm{pH}$ reaching 5.0, the concentration of cobalt in organic phase increases slowly, because the remaining cobalt in aqueous phase is little. Along with increasing extraction equilibrium $\mathrm{pH}$ from 3.9 to 5.0, the concentration of nickel in the organic phase increases slowly. After extraction equilibrium $\mathrm{pH}$ reaching 5.0, the concentration of nickel in organic phase increases drastically because the distribution coefficient increases suddenly and meanwhile the remaining nickel in aqueous phase is still rich.

\subsection{Comparing Conventional Solvent Extraction to Complexation-Assisted Solvent Extraction}

As shown in Table 4, the recovery percentage of cobalt extraction with one-stage conventional solvent extraction and complexation-assisted solvent extraction is $70 \%$ and $85 \%$, respectively. The purity of cobalt extracted with one-stage conventional solvent extraction and complexation-assisted solvent extraction is $70 \%$ and $98 \%$, respectively. The latter's high extraction percentage and purity of cobalt are due to the specific diluent and complexing reagent. The cobalt purity is $98 \%$ with a single stage of complexation-assisted solvent extraction and even still higher than $94 \%$ with six-stage conventional solvent extraction. In contrast, the cobalt extraction percentage of $95 \%$ from six-stage conventional solvent extraction is higher than $85 \%$ of a single-stage complexation-assisted solvent extraction. The six-stage conventional solvent extraction process has tried all possible means to extract cobalt but can only reach $94 \%$ purity. The separation factor of 372 by complexation-assisted solvent extraction, which effectively reduces the number of extraction stages from six to one, is five times that of the conventional solvent extraction. It also can save the cost of extraction-stripping equipment and acid/alkali consumption. The cathode materials from spent LIBs were also examined with the optimum operation parameters of complexation-assisted solvent extraction process. The results were $85 \%$ Co extraction percentage and 95\% purity because of a little impurity in spent LIBs and previous recovery procedure.

Table 4. Comparison of cobalt-nickel separation factor, cobalt recovery percentage and purity demonstrated by conventional solvent extraction and complexation-assisted solvent extraction.

\begin{tabular}{cccc}
\hline Types of Solvent Extraction in This Study & $\begin{array}{c}\text { Separation Factor } \\
\boldsymbol{\beta}_{\mathbf{C o} / \mathbf{N i}}\end{array}$ & $\begin{array}{c}\text { Co Extraction Percentage } \\
\text { (\%) }\end{array}$ & Co Purity (\%) \\
\hline Conventional solvent extraction & 72 & 95 (six stages) & 94 (six stages) \\
Complexation-assisted solvent extraction & 372 & 70 (one stage) & 70 (one stage) \\
\hline
\end{tabular}

\section{Conclusions}

We demonstrated an overall process to recover metals from spent NMC type LIBs. Leaching kinetics of $\mathrm{Li}, \mathrm{Ni}, \mathrm{Co}$ and $\mathrm{Mn}$ were studied. The results indicated the validity of linearly fitting by Avrami equation. The value of $\mathrm{n}$ in $\mathrm{H}_{2} \mathrm{SO}_{4}+\mathrm{H}_{2} \mathrm{O}_{2}$ leaching media for each metal was higher than in any other leaching media, which showed reducing agent $\mathrm{H}_{2} \mathrm{O}_{2}$ greatly increases the leaching efficiency. The optimal leaching conditions were 4- $\mathrm{N} \mathrm{H}_{2} \mathrm{SO}_{4}, 3 \% v / v \mathrm{H}_{2} \mathrm{O}_{2}, 50{ }^{\circ} \mathrm{C}$ and three hours of leaching time. Comparing with recovered cathode powder, SEM images of leached residue surface emerged plenty of 
pores with different sizes. The XRD analysis indicated that most leached residue were graphite as a result of removal of the metals.

We also performed a bench scale continuous-countercurrent-extraction process to separate metals from leachate and developed a complexation-assisted solvent extraction to improve the separation factor between cobalt and nickel. With the assist of diluent heptane and complexing reagent ammonium thiocyanate, the facile process demonstrated a separation factor 372, which is five times higher than conventional solvent extraction with a single extraction stage identically. The optimal extraction parameters were identified as follows: volume ratio of extractant to diluent (1:4), saponification percentage (60\%), diluent (heptane), complexing reagent (ammonium thiocyanate) and volume ratio of organic phase to aqueous phase (1:1). The separation tendency would be interpreted by the relationship between extraction equilibrium $\mathrm{pH}$ and $\log$ distribution coefficient. We propose that $\mathrm{Co}(\mathrm{SCN})_{2}\left(\mathrm{NH}_{4} \mathrm{SCN}\right)_{2}$ is more conducive to directly perform an ion exchange of cobalt with saponified P-507. Moreover, the number of extraction stages could be reduced from six to one, which can greatly decrease the consumption of acid, alkali and energy during the facile extraction process.

The recovered $\mathrm{Mn}, \mathrm{Co}, \mathrm{Ni}$ and $\mathrm{Li}$ could be further refined for the manufacturing of cathode material precursor and practice the circulation of cathode materials from a waste Li-ion battery to a fresh Li-ion battery. However, the interfacial properties between metal-complexing and metal-extracting speciation in the complexation-assisted solvent extraction process is essential to be studied.

Author Contributions: Conceptualization, W.-Y.W.; methodology, W.-Y.W.; formal analysis, W.-Y.W.; investigation, H.-C.Y., R.-B.X. and W.-Y.W.; data curation, W.-Y.W.; writing-original draft preparation, W.-Y.W.; writing-review and editing, W.-Y.W.; visualization, W.-Y.W.; supervision, W.-Y.W.; project administration, W.-Y.W.; funding acquisition, W.-Y.W. All authors have read and agreed to the published version of the manuscript.

Funding: This research was funded by the Ministry of Science and Technology, Taiwan (MOST 108-2218-E-324-002) and the Recycling Fund Management Board, Environmental Protection Administration, Taiwan (EPA-109-XB06).

Conflicts of Interest: The authors declare no conflicts of interest.

\section{References}

1. Stan, A.I.; Świerczyński, M.; Stroe, D.I.; Teodorescu, R.; Andreasen, S.J. Lithium ion battery chemistries from renewable energy storage to automotive and back-up power applications-An overview. In Proceedings of the 2014 International Conference on Optimization of Electrical and Electronic Equipment (OPTIM), Bran, Romania, 22-24 May 2014; IEEE: Piscataway, NJ, USA, 2014; pp. 713-720.

2. Pillot, C. The rechargeable battery market and main trends 2016-2025. In Proceedings of the 33rd Annual International Battery Seminar \& Exhibit, Fort Lauderdale, FL, USA, 20 March 2017.

3. King, S.; Boxall, N.J. Lithium battery recycling in Australia: Defining the status and identifying opportunities for the development of a new industry. J. Clean. Prod. 2019, 215, 1279-1287. [CrossRef]

4. Boxall, N.J.; King, S.; Cheng, K.Y.; Gumulya, Y.; Bruckard, W.; Kaksonen, A.H. Urban mining of lithium-ion batteries in Australia: Current state and future trends. Min. Eng. 2018, 128, 45-55. [CrossRef]

5. Pourret, O.; Faucon, M.P. Cobalt. In Encyclopedia of Geochemistry; White, W.M., Ed.; Springer International Publishing: Cham, Switzerland, 2017.

6. Zhang, X.; Xie, Y.; Lin, X.; Li, H.; Cao, H. An overview on the processes and technologies for recycling cathodic active materials from spent lithium-ion batteries. J. Mater. Cycles Waste Manag. 2013, 15, 420-430. [CrossRef]

7. Zeng, X.; Li, J.; Singh, N. Recycling of spent lithium ion battery: A critical review. Crit. Rev. Environ. Sci. Technol. 2014, 44, 1129-1165. [CrossRef]

8. Ordonez, J.; Gago, E.J.; Girard, A. Processes and technologies for the recycling and recovery of spent lithium-ion batteries. Renew. Sustain. Energy. Rev. 2016, 60, 195-205. [CrossRef]

9. Lv, W.; Wang, Z.; Cao, H.; Sun, Y.; Zhang, Y.; Sun, Z. A critical review and analysis on the recycling of spent lithium-ion batteries. ACS Sustain. Chem. Eng. 2018, 6, 1504-1521. [CrossRef] 
10. Sethurajan, M.; van Hullebusch, E.D.; Fontana, D.; Akcil, A.; Deveci, H.; Batinic, B.; Leal, J.P.; Gasche, T.A.; Kucuker, M.A.; Kuchta, K.; et al. Recent advances on hydrometallurgical recovery of critical and precious elements from end of life electronic wastes-A review. Crit. Rev. Environ. Sci. Technol. 2019, 49, 212-275. [CrossRef]

11. Velázquez-Martínez, O.; Valio, J.; Santasalo-Aarnio, A.; Reuter, M.; Serna-Guerrero, R. A critical review of lithium-ion battery recycling processes from a circular economy perspective. Batteries 2019, 5, 68. [CrossRef]

12. Zhao, S.Q.; Li, G.M.; He, W.Z.; Huang, J.W.; Zhu, H.C. Recovery methods and regulation status of waste lithium-ion batteries in China: A mini review. Waste Manag. Res. 2019, 37, 1142-1152.

13. Wang, S.G.; Tian, Y.; Zhang, X.F.; Yang, B.; Wang, F.; Xu, B.Q.; Liang, D.; Wang, L.P. A review of processes and technologies for the recycling of spent lithium-ion batteries. IOP Conf. Ser. Mater. Sci. Eng. 2020, 782, 022025. [CrossRef]

14. Larouche, F.; Tedjar, F.; Amouzegar, K.; Houlachi, G.; Bouchard, P.; Demopoulos, G.P.; Zaghib, K. Progress and status of hydrometallurgical and direct recycling of Li-Ion batteries and beyond. Materials 2020, 13, 801. [CrossRef]

15. Demarco, J.d.O.; Cadore, J.S.; Oliveira, F.d.S.d.; Tanabe, E.H.; Bertuol, D.A. Recovery of metals from spent lithium-ion batteries using organic acids. Hydrometallurgy 2019, 190, 105169. [CrossRef]

16. He, L.; Sun, S.; Mu, Y.; Song, X.; Yu, J. Recovery of lithium, nickel, cobalt, and manganese from spent lithium-ion batteries using L-tartaric acid as a leachant. ACS Sustain. Chem. Eng. 2017, 5, 714-721. [CrossRef]

17. Nayaka, G.P.; Pai, K.V.; Manjanna, J.; Keny, S.J. Use of mild organic acid reagents to recover the Co and Li from spent Li-ion batteries. Waste Manag. 2016, 51, 234-238. [CrossRef] [PubMed]

18. Nayaka, G.P.; Pai, K.V.; Santhosh, G.; Manjanna, J. Recovery of cobalt as cobalt oxalate from spent lithium ion batteries by using glycine as leaching agent. J. Environ. Chem. Eng. 2016, 4, 2378-2383. [CrossRef]

19. Nayaka, G.P.; Pai, K.V.; Santhosh, G.; Manjanna, J. Dissolution of cathode active material of spent Li-ion batteries using tartaric acid and ascorbic acid mixture to recover Co. Hydrometallurgy 2016, 161, 54-57. [CrossRef]

20. Chen, X.; Luo, C.; Zhang, J.; Kong, J.; Zhou, T. Sustainable recovery of metals from spent lithium-ion batteries: A green process. ACS Sustain. Chem. Eng. 2015, 3, 3104-3113. [CrossRef]

21. Zeng, X.; Li, J.; Shen, B. Novel approach to recover cobalt and lithium from spent lithium-ion battery using oxalic acid. J. Hazard. Mater. 2015, 295, 112-118. [CrossRef]

22. Li, L.; Qu, W.; Zhang, X.; Lu, J.; Chen, R.; Wu, F.; Amine, K. Succinic acid-based leaching system: A sustainable process for recovery of valuable metals from spent Li-ion batteries. J. Power Sources 2015, 282, 544-551. [CrossRef]

23. Sun, L.; Qiu, K. Organic oxalate as leachant and precipitant for the recovery of valuable metals from spent lithium-ion batteries. Waste Manag. 2012, 32, 1575-1582. [CrossRef]

24. Joulié, M.; Laucournet, R.; Billy, E. Hydrometallurgical process for the recovery of high value metals from spent lithium nickel cobalt aluminum oxide based lithium-ion batteries. J. Power Sources 2014, 247, 551-555. [CrossRef]

25. Muzayanha, S.U.; Yudha, C.S.; Hasanah, L.M.; Gupita, L.T.; Widiyandari, H.; Purwanto, A. Comparative Study of Various Kinetic Models on Leaching of NCA Cathode Material. Indones. J. Chem. in press. [CrossRef]

26. Shuva, M.A.H.; Kurny, A.S.W. Hydrometallurgical Recovery of Value Metals from Spent Lithium Ion Batteries. Am. J. Mater. Sci. Technol. 2013, 1, 8-12.

27. Jha, M.K.; Kumari, A.; Jha, A.K.; Kumar, V.; Hait, J.; Pandey, B.D. Recovery of lithium and cobalt from waste lithium ion batteries of mobile phone. Waste Manag. 2013, 33, 1890-1897. [CrossRef]

28. Liu, T.C.; Chen, J.; Li, H.L.; Li, K. An integrated process for the separation and recovery of valuable metals from the spent $\mathrm{LiNi}_{0.5} \mathrm{Co}_{0.2} \mathrm{Mn}_{0.3} \mathrm{O}_{2}$ cathode materials. Sep. Purif. Technol. 2020, 245, 116869. [CrossRef]

29. Chu, W.; Zhang, Y.L.; Chen, X.; Huang, Y.G.; Cui, H.Y.; Wang, M.; Wang, J. Synthesis of $\operatorname{LiNi}_{0.6} \mathrm{Co}_{0.2} \mathrm{Mn}_{0.2} \mathrm{O}_{2}$ from mixed cathode materials of spent lithium-ion batteries. J. Power Sources 2020, 449, 227567. [CrossRef]

30. Chen, L.; Tang, X.; Zhang, Y.; Li, L.; Zeng, Z.; Zhang, Y. Process for the recovery of cobalt oxalate from spent lithium-ion batteries. Hydrometallurgy 2011, 108, 80-86. [CrossRef]

31. Zhao, J.J.; Zhang, B.L.; Xie, H.W.; Qu, J.K.; Qu, X.; Xing, P.F.; Yin, H.Y. Hydrometallurgical recovery of spent cobalt-based lithium-ion battery cathodes using ethanol as the reducing agent. Environ. Res. 2020, 181, 108803. [CrossRef] 
32. Meshram, P.; Pandey, B.D.; Mankhand, T.R. Hydrometallurgical processing of spent lithium ion batteries (LIBs) in the presence of a reducing agent with emphasis on kinetics of leaching. Chem. Eng. J. 2015, 281, 418-427. [CrossRef]

33. Urbańska, W. Recovery of $\mathrm{Co}, \mathrm{Li}$, and $\mathrm{Ni}$ from spent Li-ion batteries by the inorganic and/or organic reducer assisted leaching method. Minerals 2020, 10, 555. [CrossRef]

34. Kaksonen, A.H.; Deng, X.; Bohu, T.; Zea, L.; Khaleque, H.N.; Gumulya, Y.; Boxall, N.J.; Morris, C.; Cheng, K.Y. Prospective directions for biohydrometallurgy. Hydrometallurgy 2020, 195, 105376. [CrossRef]

35. Boxall, N.J.; Cheng, K.Y.; Bruckard, W.; Kaksonen, A.H. Application of indirect non-contact bioleaching for extracting metals from waste lithium-ion batteries. J. Hazard. Mater. 2018, 360, 504-511. [CrossRef]

36. Calvert, G.; Kaksonen, A.H.; Cheng, K.Y.; Yken, J.V.; Chang, B.; Boxall, N.J. Recovery of metals from waste lithium ion battery leachates using biogenic hydrogen sulfide. Minerals 2019, 9, 563. [CrossRef]

37. Wang, W.Y.; Yen, C.H.; Lin, J.L.; Xu, R.B. Recovery of high-purity metallic cobalt from lithium nickel manganese cobalt oxide (NMC)-type Li-ion battery. J. Mater. Cycles Waste Manag. 2019, 21, 300-307. [CrossRef]

38. Valadares, A.; Valadares, C.F.; de Lemos, L.R.; Mageste, A.B.; Rodrigues, G.D. Separation of cobalt and nickel in leach solutions of spent nickel-metal hydride batteries using aqueous two-phase systems (ATPS). Hydrometallurgy 2018, 181, 180-188. [CrossRef]

39. Chen, W.S.; Ho, H.J. Recovery of valuable metals from lithium-ion batteries NMC cathode waste materials by hydrometallurgical methods. Metal 2018, 8, 321. [CrossRef]

40. Hong, H.S.; Kim, D.W.; Choi, H.L.; Ryu, S.S. Solvent extraction of Co, Ni and Mn from NCM sulfate leaching solution of $\mathrm{Li}(\mathrm{NCM}) \mathrm{O}_{2}$ secondary battery Scraps. Arch. Met. Mater. 2017, 62, 1011-1014. [CrossRef]

41. Wang, W.Y.; Yen, C.H.; Hsu, J.K. Selective recovery of cobalt from the cathode materials of NMC type Li-ion battery by ultrasound-assisted acid leaching and microemulsion extraction. Sep. Sci. Technol. 2019, 34, 1-8. [CrossRef]

42. Onghena, B.; Valgaeren, S.; Vander Hoogerstraete, T.; Binnemans, K. Cobalt(II)/nickel(II) separation from sulfate media by solvent extraction with an undiluted quaternary phosphonium ionic liquid. RSC Adv. 2017, 57, 35992-35999. [CrossRef]

43. Baba, Y.; Kubota, F.; Goto, M.; Cattrall, R.W.; Kolev, S.D. Separation of cobalt(II) from manganese(II) using a polymer inclusion membrane with $\mathrm{N}$-[N,N-di(2-ethylhexyl)aminocarbonylmethyl]glycine (D2EHAG) as the extractant/carrier. J. Chem. Technol. Biot. 2016, 91, 1320-1326. [CrossRef]

44. Swain, B.; Mishra, C.; Jeong, J.; Lee, J.C.; Hong, H.S.; Pandey, B.D. Separation of Co(II) and Li(I) with Cyanex 272 using hollow fiber supported liquid membrane: A comparison with flat sheet supported liquid membrane and dispersive solvent extraction process. Chem. Eng. J. 2015, 271, 61-70. [CrossRef]

45. Wang, M.M.; Zhang, C.C.; Zhang, F.S. An environmental benign process for cobalt and lithium recovery from spent lithium-ion batteries by mechanochemical approach. Waste Manag. 2016, 51, 239-244. [CrossRef] [PubMed]

46. Wang, M.M.; Zhang, C.C.; Zhang, F.S. Recycling of spent lithium-ion battery with polyvinyl chloride by mechanochemical process. Waste Manag. 2017, 67, 232-239. [CrossRef]

47. Kislik, V. Competetive complexation/solvation theory of solvent extraction. II. solvent extraction of metals by acidic extractants. Sep. Sci. Technol. 2002, 37, 2623-2657. [CrossRef]

48. Rydberg, J.; Cox, M.; Musikas, C.; Choppin, G.R. Solvent Extraction and Praciice, 2nd ed.; Marcel, D., Ed.; Inc.: New York, NY, USA, 2004; p. 1.

49. Pagnanelli, F.; Moscardini, E.; Altimari, P.; Abo, A.T.; Toro, L. Cobalt products from real waste fractions of end of life lithium ion batteries. Waste Manag. 2016, 51, 214-221. [CrossRef] [PubMed]

50. Todd, D.B. Solvent Extraction. In Fermentation and Biochemical Engineering Handbook, 3rd ed.; Vogel, H.C., Todaro, C.M., Eds.; Elsevier: Waltham, MA, USA, 2014; p. 225.

51. Li, D.; Li, H.; Danilov, D.L.; Gao, L.; Zhou, J.; Eichel, R.A.; Yanga, Y.; Notten, P.H.L. Temperature-dependent cycling performance and ageing mechanisms of $\mathrm{C}_{6} / \mathrm{LiNi}_{1 / 3} \mathrm{Mn}_{1 / 3} \mathrm{Co}_{1 / 3} \mathrm{O}_{2}$ batteries. J. Power Sources 2018, 396, 444-452. [CrossRef]

52. Hu, J.P.; Sheng, H.; Deng, Q.; Ma, Q.; Liu, J.; Wu, X.W.; Liu, J.J.; Wu, Y.P. High-Rate Layered Cathode of Lithium-Ion Batteries through Regulating Three-Dimensional Agglomerated Structure. Energies 2020, 13, 1602. [CrossRef] 
53. Zhou, X.W.; Yang, Y.; Ma, J.T.; Zhang, K.H.; Song, J.; Wang, L.; Liu, B.; Zhang, J.; Lu, Z.M.; Tang, Y.P. Effects of purification on the properties and microstructures of natural flake and artificial graphite powders. Nucl. Eng. Des. 2020, 360, 110527. [CrossRef]

54. Khawam, A.; Flanagan, D.R. Solid-state kinetic models: Basics and mathematical fundamentals. J. Phys. Chem. 2006, 110, 17315-17328. [CrossRef]

55. Zhang, X.H.; Cao, H.B.; Xie, Y.B.; Ning, P.G.; An, H.J.; You, H.X.; Nawaz, F. A closed-loop process for recycling $\mathrm{LiNi}_{1 / 3} \mathrm{Co}_{1 / 3} \mathrm{Mn}_{1 / 3} \mathrm{O}_{2}$ from the cathode scraps of lithium-ion batteries: Process optimization and kinetics analysis. Sep. Purif. Technol. 2015, 150, 186-195. [CrossRef]

56. Joo, S.H.; Shin, S.M.; Shin, D.; Oh, C.H.; Wang, J.P. Extractive separation studies of manganese from spent lithium battery leachate using mixture of PC88A and Versatic 10 acid in kerosene. Hydrometallurgy 2015, 156, 136-141. [CrossRef]

57. Nguyen, V.T.; Lee, J.C.; Jeong, J.; Kim, B.S.; Pandey, B.D. Selective recovery of cobalt, nickel and lithium from sulfate leachate of cathode scrap of Li-ion batteries using liquid-liquid extraction. Met. Mater. Int. 2014, 20, 357-365. [CrossRef]

58. Ghebghoub, F.; Barkat, D. The effect of diluents on extraction of copper(II) with di(2-ethylhexyl)phosphoric acid. J. Coord. Chem. 2009, 62, 1449-1456. [CrossRef]

(C) 2020 by the authors. Licensee MDPI, Basel, Switzerland. This article is an open access article distributed under the terms and conditions of the Creative Commons Attribution (CC BY) license (http://creativecommons.org/licenses/by/4.0/). 